\title{
Institutional Voids and the Philanthropization of CSR Practices: Insights from Developing Economies
}

\author{
Frederick Ahen ${ }^{1, *}$ and Joseph Amankwah-Amoah ${ }^{2}$ \\ 1 Turku School of Economics, University of Turku, 20500 Turku, Finland \\ 2 Kent Business School, University of Kent, Kent CT2 7FS, UK; J.Amankwah-Amoah@kent.ac.uk \\ * Correspondence: Frederick.Ahen@utu.fi
}

Received: 31 May 2018; Accepted: 4 July 2018; Published: 10 July 2018

\begin{abstract}
Corporate social responsibility (CSR) practices and conceptions vary across sectors and nations. However, there is a general tendency among academics and practitioners to present CSR in Africa as activities characterized by philanthropy due to the existence of institutional voids. This review of the current literature demonstrates that weak institutions lead to weaker bargaining powers designed through the historical and geopolitical institutional frameworks of international business and global governance systems. Accordingly, multinational corporations (MNCs) take advantage of such weaknesses to define CSR on their own terms by replacing the ideal responsible and sustainable innovations with ad hoc philanthropy that diverts the attention from the negative consequences of neoliberal 'structures of accumulation'. This is akin to aid that hardly contributes to structural changes, but rather leads to complacency, corruption, dependency, boutique projects, disguised exploitation, and the misuse of corporate political power to achieve corporate bottom lines. The implications of the results are vast, and they are generalizable to all weaker institutional settings. Thus, weaker institutions create the necessary regulatory, political, economic, and governance climate that perpetuates a pattern of abuses and ethical violations that are then masked with philanthropy. It is argued that the fundamental institutional and geopolitical contexts within which MNCs interact with nation states cannot be ignored in any comprehensive analysis that seeks to meaningfully shed light on the comparative differences of CSR practices. The neglect of the web of contextual, historical, and geopolitical issues in which CSR is entrenched and framed diverts attention from the origins of the socio-economic and environmental questions to philanthropy as a final solution, which has hitherto been perpetuated with undesirable outcomes.
\end{abstract}

Keywords: Africa; captured institutions; comparative CSR; developing economies; institutional void; paradigm change; strategic corporate responsibility

\section{Introduction}

Corporate social responsibility (CSR) has been identified as one of the essential factors for business success and sustainable development in the 21st century [1,2]. Indeed, the need to foster sustainable development [3] through authentic CSR practices has never been greater [4,5]. Foreign direct investments (FDIs) by multinational corporations (MNCs) are a very important part of the analysis of development issues [5-7] and the political interactions of firms and nation states [8,9]. Interestingly, there are complex reasons why the CSR cases in developing economies are at odds with those of industrialized nations. The issue of defining what constitutes good management practices revolves around an array of deep-rooted questions of designed institutional deficiencies, socio-economic disequilibrium, environmental turbulence [10,11], historical bias, and academic hegemony [12-15]. CSR broadly refers to the organization's socio-economic, legal, ethical, and discretionary obligations toward society and the environment [16,17]. Accordingly, CSR represents "actions that appear to 
further some social good beyond the interest of the firm and that which is required by law" [18]. However, within the general CSR discourse, there are contextual intricacies, complicated contradictions, knowledge gaps, and unanswered questions that comparative studies can offer clinical socio-economic diagnosis to, while explaining their contours in order to meaningfully expand our understanding. This is because CSR cannot consist of actions that appear to be good on the surface; they must be actions that actually seek positive socio-economic and environmental change. In light of the above, this study seeks to answer the following question:

How do institutional voids account for the varieties of CSR practices across Africa that differ from the CSR practices of highly industrialized nations?

This study problematizes the taken-for-granted assumption that tends to suggest that institutional deficiencies in the socio-economic, regulatory, and political systems across Africa must be solved with mainly philanthropy-based CSR [19-22], and that corporations must step in [23] where there are regulatory and governance voids, as well as a lack of public utilities and amenities, otherwise called the politicization of corporate responsibility or political CSR [24]. Moreover, the marginalized live in the communities where extractive operations take place, water bodies are contaminated and forests as a source of livelihood are ploughed down $[2,14,25,26]$. The proper question is, why are gifts not a major feature of CSR in the West [27], but the handouts that capture headlines are seen as the desirable direction in developing economies [28] where most of the extractivism [25] and other forms of structural violence take place $[14,25]$ The Congo and many resource-rich African countries speak volumes regarding this protracted issue of "planetary vandalism" [2] and looting machines $[25,26,29]$ that hardly see accountability [30]. It is this ignored tragedy and the industrialized world's unquenchable thirst for resources and overconsumption that in part fuel the corrupt governance and poverty that President Dr. Horst Köhler (2014) [31] refers to as "the impossibility of speaking about Africa" and its silenced subjectivities and marginalization, especially in mainstream journals [12,15]. It makes for uncomfortable reading about how colonial and imperial projects of subjugation and illegal appropriation served as the foundations for inequality [13,32-34]. This implies that the dominion of the West (spheres of influence) in all of the geopolitical, economic, regulatory and military spheres, and the weak resistance of the rest offers an important analytical clue about the genesis of the present state of affairs. This means that no sincere inquiry into the CSR issues in Africa, and by extension the developing world, can ignore the above crucial analytical factors. Therefore, this study asks a follow-up question:

Is it possible then that communities in weaker institutions accept philanthropy as a substitute for genuine sustainability-oriented CSR because they lack any bargaining power or choice that allows them to press home their demands?

Now, the nature of the question is as philosophical as it is empirical. However, there are other conceptual quandaries to be resolved first. This is because knowledge of CSR practices is both contextual, perspectival [35], and historically contingent [36]. There is enormous room for constructing a comprehensive theoretical framework for explaining how institutions or institutional deficiencies shape CSR practices. Are there missing dots in the puzzle that can be pieced together to better explain the varieties of CSR practices beyond the institutional void hypothesis [11,23,37], or in other words, the lack of government capacity to fix socio-economic problems or the lack of enforcement mechanisms [5,20,38] CSR has political roots [39], and these roots must be traced from their exogenous (geopolitics) and endogenous (national) politics, mores, polities, and institutions [40], which are mostly unaddressed especially in the mining sector [41]. More prominently, MNCs now have a bigger role as major actors in global governance [42-44]. This particular governance role of capitalist firms in democracies must be questioned $[2,45,46]$.

The irresponsible use of corporate political power in influencing local politics $[47,48]$ is known. For example, it includes advertising power in spreading cultural commodities, management by 
dispossession [26,34,49], and abuse of monopoly statuses [4,48]. Corporations exercise political process and political influence through lobbying [50]. They also shape public opinion through political maneuvers [51]. The intent of profit maximization for serving the interest of shareholders reigns supreme [52-54]. That is, similar to most non-state actors, MNCs are technologies that are used in global governance by private actors [42,55]. In weaker institutions, MNCs hardly act justly, given the weaker bargaining positions of these communities. Thus, for example, human rights abuses and the wrong use of corporate political power are common [26,30], but unfortunately, due to legal loopholes, deviant firms hardly face any real consequences in host nations besides government complicity and weakened regulatory institutions [41]. This is because the countries where they commit such insidious acts do not have the military power to ensure self-defense and retaliation. According to a 2014 CIA report, "International affairs will increasingly be determined by large and powerful organizations rather than governments" from 2015 and beyond [44]. There is enough evidence of that, and such behaviors negatively affect good companies within the same ecosystem. In fact, in the broad areas of the United Nation's Sustainable Development Goals (SDGs), some MNCs seem to be responding with new ecologically sound strategies, whilst their own governments are pulling out of climate change deals. In some developing countries, some governments are committed, whilst others do business as usual.

For this study, 'Western' refers to the United States (US)/Canada, the European Union (EU), and by geopolitical extension Australia. These are characterized by historical and cultural ties, and most importantly, a relatively high gross domestic product (GDP) per capita and advanced forms of industrialization. The latter is the result of being able to acquire much-needed resources and raw materials from the periphery $[33,56,57]$ in part through warfare and imperialism [32,58], which dispossessed others of their resources. This definition of what accounts for the early industrialization in the West is almost always left unarticulated in management research (except by a few critical scholars), although it has material consequences in the present state of affairs. Most importantly, albeit their international differences, some corporations have been committed to a common solidarity in ensuring the success of their resource-seeking agenda since the Berlin Conference in 1885 [42,59]. This in part explains the comparative and competitive advantages resulting from the availability of initial resource endowments to finance innovations in the West, and why resources are still lacking in low-income countries. There is a complex set of reasons why the developing world is under-resourced financially; "accumulation by dispossession" [60-62] is one major explanatory factor. Currently, Western CSR is mostly innovation-focused in response to emerging environmental and health challenges (over the long term), especially in Scandinavia and to a great degree the West as a whole [27]. This is also because there is a political will to dedicate available resources to sustainability issues. CSR in Africa by contrast is philanthropy [28] and public relations (PR)-focused legitimacy-seeking (in the short term) [63] with a flourish of boutique projects for cameras. This is not to suggest that there are no exceptions. However, we are dealing with what appears to be the rule and not the exceptions. This is not to suggest that CSR in Europe is the same as CSR in the United States. There is a clear transatlantic gap; even in Europe, the Scandinavians (still with national differences) are different from the wider central Europe and the United Kingdom (UK). This of course is explained by the national business systems and the varieties of Scandinavian capitalism that are oriented toward welfare and sustainability [64].

Besides asymmetrical geopolitical statuses, the defining difference between the 'advanced' world(s) and developing world(s) is a socio-economic, medico-techno-scientific, and politicoinstitutional, and military gap on one hand, and inequalities in general welfare on the other; the historical note of looting and "planetary vandalism" [2] is conveniently forgotten [65], and the danger is that it continues unabated. The exploitation of Africa is a well-known fact as encapsulated in the recent comments of Pope Francesco to Reuters:

We must invest in Africa, but invest in an orderly way and create employment, not go there to exploit it. When a country grants independence to an African country it is from the ground up - but the subsoil is not independent. And then people (outside Africa) complain about hungry Africans coming 
here. There are injustices there!" "in our collective unconscious there is something inside us that says Africa must be exploited. [65]

The subsoil that remains captured, not independent, refers to the soil beneath the surface of the Earth that contains the gold, diamond, bauxite, crude oil, natural gas, and uranium, as well as the roots of the vegetation on which the populations depend for their survival and livelihood. Thus, whoever controls the value chains has the most power to decide about the life and death of others [56]. If the assessment of this influential world leader with a deep knowledge of world affairs and history is correct, then it gives us insights into the eternally captured resources as a plausible explanation of the origins of poverty and under-development. Then, under such circumstances, charity instead of restitution and economic justice answers a slightly different question. Therefore, if African governments ignore such insights, then as the axiom goes, no one is more hopelessly enslaved than the nation that falsely believes that she is free.

It must be noted that undesirable socio-economic and environmental issues are not unique to developing countries [6]. Inequality in the US, UK, and southern Europe has been on the rise since the 2007/2008 financial crisis [66,67]. Now, there are 5,000,000 people living in absolute poverty in Italy according to Istat [68], and the number of poor in the UK is rising in the millions as well. Rising poverty, falling incomes, and homelessness are also acute problems in the US. At the same time, there is a rising middle class in the midst of poverty all across Africa and other developing and emerging economies [69]. This means that one cannot hijack the focus of the study by misconstruing it as some anti-West rhetoric. Rather, it is about the search for new mechanisms through which the major actors (governments, firms, non-governmental organizations (NGOs), and hybrid organizations) can begin to address the roots of the problem instead of the symptoms. Global interconnectedness has meant that under-development anywhere affects progress everywhere. For example, if an epidemic worsens in a far-flung country due to a lack of finance, health infrastructure, and proper management or governance (e.g., the 2014 outbreak of Ebola in some parts of West Africa), anybody in the rich US, UK, or Switzerland has a rational cause to be worried, because we are easily affected directly or indirectly by global occurrences, whether they are economic recessions, political turmoil, or epidemics. These problems also include actions that lead to global warming and climate change and the destruction of biodiversity [2] on the only planet Earth, which we all call home. A threat to life and the environment anywhere is a threat to life and the environment everywhere. Therefore, seeking the optimal solutions to global well-being by de-emphasizing the regressive and temporary solutions such as charity by economic agents who are playing 'Mother Theresa' is not only objectively logical, it is also ethical for all intents and purposes because of our global interconnectedness and common future.

Physicians diagnose diseases before prescribing cures whereas, unfortunately, some social scientists seem to prescribe fancy solutions without a proper diagnosis of the problem. In the long term, this only worsens the pathology because the solution misses the point. Nevertheless, those scientists' jobs are maintained to search for a cure for the same ailment under a new label [14], thereby perpetuating the problem. It is easy to side with the powerful and play the game, but that is nothing short of cowardice and weakness. There is no honor, dignity, humanity, or courage in taking sides with the powerful (who abuse), remaining indifferent, refusing to seek the truth no matter how inconvenient, or ignoring the rest who have become victims of planetary vandalism and looting by governments and corporations $[2,70]$. Therefore, this study demonstrates that academia does not seek to ignore those who are adversely affected by CSR tricks [71], but rather seeks truth and justice that can potentially bring socio-economic advancement. Herein lays the relevance of this paper.

For the above reasons, we do not restrict our definition of corporate responsibility only to business enterprises practicing voluntary CSR, which will always prioritize shareholders at the expense of moral and distributive expectations. Rather, seen from the grand scheme of things, corporate responsibility refers to the proactive duty/action of major actors in global governance and socio-economic and political organizing (firms, governments, NGOs, and international hybrid organizations, as well as multilateral, national, or local entities) because of their intertwined spheres of influence and 
quasi-indistinguishable and functionally overlapping nature. These actors make decisions, trade-offs, and choices based on scarce resources, and their operations make them accountable because they have socio-ethical, bio-economic, political, and environmental consequences that have ramifications on health, the environment, and distributive justice beyond their particular context of operations.

\section{Distributive Injustice-Government-Firm Connivance as Origins of Inequality}

Currently, environmental degradation, especially air and water pollution, have now led to chronic diseases globally [2], while the concession of land to multinationals for mining and palm oil plantations [49] has led to the loss of livelihoods in the resource-abundant countries of Africa and South America [25]. This has brought about displacement, the abuse of human rights, and the undermining of human dignity [2], or what Harvey [60] calls "accumulation by dispossession", which leads to perilous migration in search of economic opportunities. The land-grabbing phenomenon, for example, can be seen as the result of several "inter-relating processes of privatization and financialization", which are some of the central pillars of neoliberal capitalism [72,73]. This is "fuelled by 'the management and manipulation of crises' - and particularly the discursive emphases on multiple 'scarcities' in policy debates-[as well as] ... 'state redistributions', whereby the state allies with capitalist business interests offer concessionary terms, tax breaks, and subsidies to support investment" (Harvey, cited in White et al. [73]). These are the big issues that require attention, but the weak stakeholders are way below par to contend with both their own governments and corporate juggernauts, leading to the acceptance of alms, which is albeit an imperfect substitute.

Consider further that a small minority of Africans keep getting ultra-wealthy whilst the larger majority suffers in poverty according to the 2017 Honest Account report written by a coalition of several NGOs [74]. There is currently around 165,000 high net-worth Individuals who reside in Africa along with the poor. These individuals control a combined of $\$ 860$ billion (Africa Wealth Report 2016 [75]). In 2018, there are 23 billionaires in Africa with a combined wealth of nearly $\$ 76$ billion [76]. Their looted money is quietly kept low tax and in secretive offshore accounts in the Channel Islands, Switzerland, and the UK [75]. According to the conservative estimates by Gabriel Zucman of the London School of Economics, ultra-wealthy Africans held around \$500 billion in tax havens in 2014 [77]. This amounts to 30\% of all of Africa's financial wealth. Clemente et al. (2017) [78] argued that these elites have stolen $\$ 15$ billion from their state or people in unpaid taxes [77]. Table 1 below shows the current state of affairs.

Table 1. Africa's total loss in billions resulting from corporate irresponsibility; source: Honest Accounts 2017 [74]. FDI: foreign direct investments.

\begin{tabular}{cccc}
\hline Inflows & $\begin{array}{c}\text { Latest Available Annual } \\
\text { Figure (\$ Billion) }\end{array}$ & Outflows & $\begin{array}{c}\text { Latest Available Annual } \\
\text { Figure (\$ Billion) }\end{array}$ \\
\hline Net private grants & 11.8 & $\begin{array}{c}\text { Debt payments by } \\
\text { governments }\end{array}$ & 18.0 \\
\hline $\begin{array}{c}\text { Decrease in international } \\
\text { reserve holdings }\end{array}$ & 20.7 & $\begin{array}{c}\text { Debt payments by } \\
\text { private sector }\end{array}$ & 0.8 \\
\hline Loans to governments & 32.8 & $\begin{array}{c}\text { Increase in international } \\
\text { reserve holdings }\end{array}$ & 32.4 \\
\hline $\begin{array}{c}\text { Loans to private sector } \\
\text { (FDI and non-FDI) }\end{array}$ & 20.6 & $\begin{array}{c}\text { Multinational company } \\
\text { profits }\end{array}$ & 67.6 \\
\hline Net portfolio equity & 7.2 & Illicit financial outflows & 3.8 \\
\hline Net FDI equity & 15.8 & Outward remittances & 6.0 \\
\hline Inward remittances & 31.2 & 'Brain drain' & \\
\hline
\end{tabular}


Table 1. Cont.

\begin{tabular}{|c|c|c|c|}
\hline Inflows & $\begin{array}{l}\text { Latest Available Annual } \\
\text { Figure (\$ Billion) }\end{array}$ & Outflows & $\begin{array}{l}\text { Latest Available Annual } \\
\text { Figure (\$ Billion) }\end{array}$ \\
\hline Official aid from OECD & 19.1 & Illegal logging & 17.0 \\
\hline $\begin{array}{c}\text { Official aid from } \\
\text { non-OECD countries }\end{array}$ & 0.6 & Illegal fishing & 1.7 \\
\hline Debit interest received & 1.8 & $\begin{array}{c}\text { Illegal trade in } \\
\text { wildlife/plants and } \\
\text { poaching }\end{array}$ & 10.0 \\
\hline \multirow{3}{*}{ Total } & \multirow{3}{*}{161.6} & $\begin{array}{l}\text { Climate change } \\
\text { adaptation costs }\end{array}$ & 10.6 \\
\hline & & $\begin{array}{l}\text { Climate change } \\
\text { mitigation costs }\end{array}$ & 26.0 \\
\hline & & Total & 202.9 \\
\hline
\end{tabular}

It has been argued that the philanthropy thesis for developing economies is therefore used as a hoodwink mechanism to divert the attention from pressing socio-economic and environmental issues, as well as the misuse of corporate political power that leads to mega-corruption, the underpricing of resources, and non-payment of taxes [74,78]. Why should those who have so much money and resources be turned into the face of poverty [74] Globally, our knowledge about business and society issues is incomplete, but developmental [17,79-81]. Context-wise, our knowledge of the business and society nexus, remains only surface-deep, particularly in Africa, and attempts at investigating intractable contemporary issues remain on an elementary level at best [82]. That Africa's economic history during and 'after' colonialism has shaped the present is mostly ignored in management literature [58]. This major historico-geographical and political point needs recognition [83]. However, it seems that either management scholars are happy to ignore it, or they just do not know. This feeds into the current gaps in CSR literature when it comes to Africa, its people, culture, markets, and the way that African businesses and governments organize themselves for responsible business with MNCs. All of this reinforces the current narrative made up of ethnocentric, epistemological claims and domesticated criticisms that constantly maintain hierarchical structures of truth [84]. By recognizing these critical caveats, we can build on, refine, and refute existing knowledge claims that are based on novel evidence and/or convincing logic. We can also speak for those who are left at the margins and cannot speak for themselves $[70,85,86]$. This, in part, is how we advance knowledge and energize the debate on CSR, especially given the paucity of comparative studies and the abundance of compartmentalized studies that resist change by upholding the status quo of hegemonic views $[14,87]$. The remainder of the paper is structured as follows. First, we explain the research approach based on an institutional void, followed by the novelty of the study; i.e., why CSR cannot be reduced to philanthropy after presenting the historical antecedents of CSR across Africa. Discussions then precede the conclusions and policy recommendations.

\section{Understanding CSR: Conceptual Development}

The nature of CSR actions mutates with context, not the content (Figure 1). Thus, this explains why some firms/organizations enact CSR that actually meets contextual needs with long-term sustainable innovations that lead to structural socio-economic changes, whilst other firms embark on short-term PR legitimating tactics [71]. The strength of institutions vis-à-vis colossal corporate political power shapes this. The moderating factor is whether or not the concerned communities lack or have stake and power to define corporate actions in their own backyard, as is the case in the industrialized world. 
Understanding the CSR regime from the perspective of time and within an institutional context [88] comprises a mass of technical and normative elements: the socio-economic and technical specifics that embody the national CSR dynamics. This means that business and society issues present very complex epistemological, ontological, and contextual questions that require innovative methods and approaches when studying them. This study draws on the literature on institutional voids, including their definitions and comparative linkages with CSR practices in the industrialized West and emerging Africa. Of course, this dichotomy is ever more useless given the new geographies of wealth distribution [66,69], which on one hand are increasing affluence across Africa $[69,89]$ and on the other are increasing poverty in the West [67]. We seek to uncover the potential flaws, in-built limitations, and neglected factors in the conceptualization of CSR in Africa in its diversity and contradictions. The objectives of this study are to:

(i) Map out the terrain of existing research on CSR in Africa whilst weighing the hierarchies of credibility of existing theories with systematic doubt.

(ii) Compare CSR practices in Africa with CSR practices in the West beyond the institutional void hypothesis. This dialectical approach based on a CSR literature-mapping exercise introduces the hypothesis of pluriversal polities and paradigms in explaining why CSR cannot be defined by a label, but rather by actual practices that lead to positive socio-economic transformation.

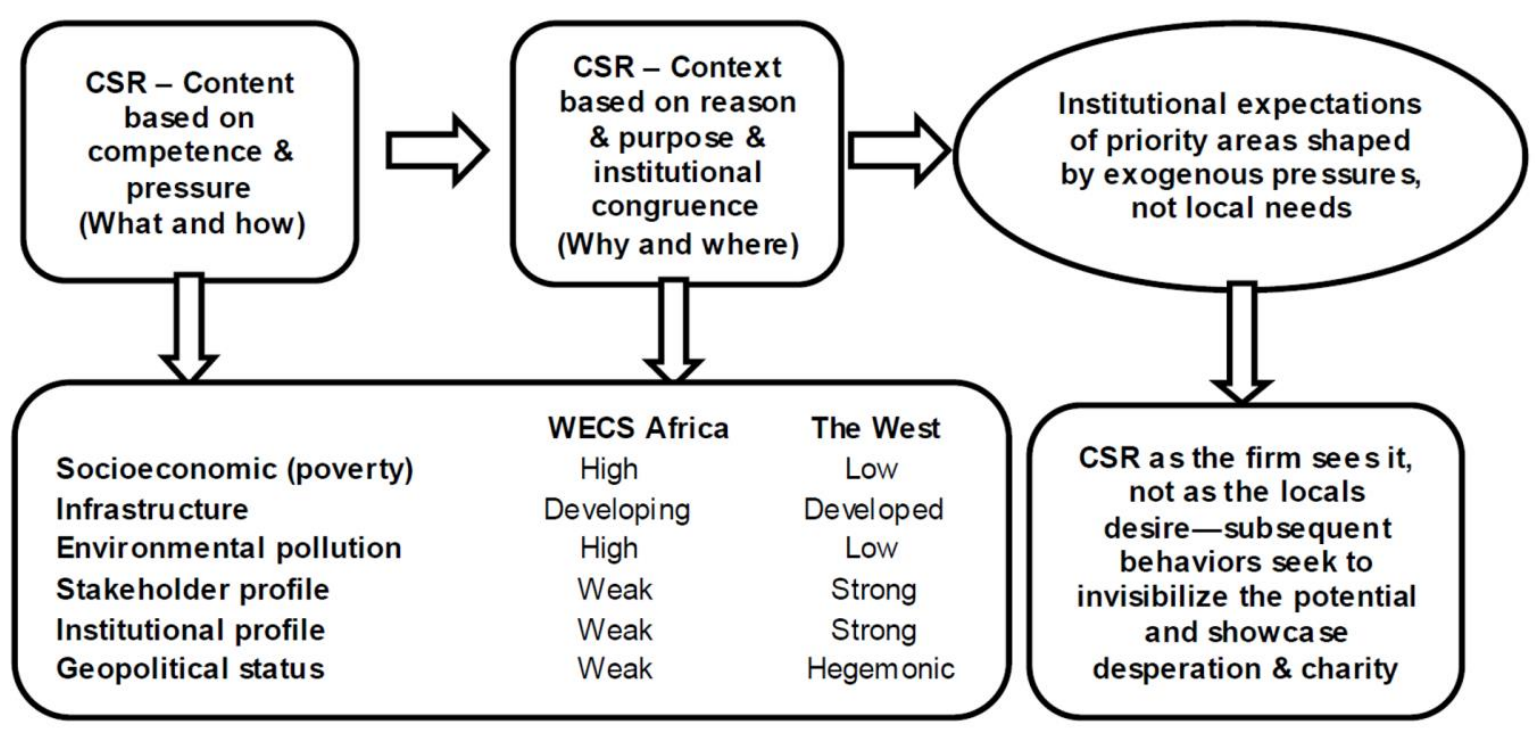

Figure 1. Institutional definitions of content and context of corporate social responsibility (CSR). WECS Africa = West, East, Central, and Southern Africa.

Our analysis will hopefully redirect attention toward a more comprehensive and updated conceptualization of different (or non-Western) institutions that are not deficient institutions per se, but are simply different in the ways that they shape CSR practices. The idea here is not only to punch holes into the existing, mostly silo narrative of CSR across 54 countries in Africa, but also to provide concrete evidence that challenges or corroborates the paradigm of expectation (to use the words of Neil deGrasse Tyson), which reinforces and perpetuates a natural tendency to take untested assumptions for granted. Such assumptions include the maxim that "the poor need help", although why and how they became poor is ignored in the analysis.

\section{Contextualizing CSR in Africa}

Although written in a measured tone and polished academese, CSR literature on Africa is mostly oblivious to the serious contextual and historical questions whilst alluding to the same 
taken-for-granted damaging vocabularies, which includes words such as: 'help', 'aid', 'philanthropy' to the 'poor', 'disadvantaged', 'underdeveloped', 'least advanced', 'Third World', 'periphery', 'marginalized', 'have-nots'. All of these words have been in vogue since the colonial era [90], and they are presented with cringeworthy images suggesting that Africa is synonymous to the four Ds-death, disease, destruction and desperation-and must be helped. At first glance, the need to help the 'have-nots' seems quite convincing and emotionally appealing. However, a deeper analysis immediately announces the short-sighted nature, and the consequences that it produces such as dependency, complacency, and digression from the main problems, similar to aid programs [90-92]. Wrong assumptions and doom-laden clichés that are presented as facts and theories [93] undermine responsible management practices. However, it is hard to see any serious reaction against such an abuse of the academic platform. It is interesting to see the level of naïveté and one-sidedness with which so many write about Africa vis-à-vis the West [94]. The narrative is mostly about how we can help them (the others), rather than these countries came to this, or what they are doing to change the situation. Here, the emerging literature then suggests an African economic renaissance [95], increasing intra-African FDI-“Africa rising out of itself: The growth of intra-African FDI" [96,97], and the changing dynamics in African international business across Africa [98].

First, WECS (West, East, Central and Southern) Africa, or what others call Sub-Saharan Africa, is treated as a monolithic region, and North Africa is treated as another [99]. This is an oversimplification that is intellectually misleading. See the definition of WECS Africa by Ahen [6], which clarifies the heterogeneous nature of countries and regions across Africa. Ghana is not Somalia, and South Africa is not Chad. There are regional characteristics, and within the nations, there are different regions based on whether they are Francophone, Anglophone, Lusophone, Arab-speaking, or a mixture. None of these even does justice to the arbitrary partitioning of Africa and the displaced ethnic groups scattered in different countries who share the same cultural experiences, and therefore may have similar institutional expectations. Also, the economies and types of market capitalisms that are pursued differ enormously [100]. A cursory look at the CNN Market Place Africa demonstrates that the CEOs of companies confess their ignorance prior to operating anywhere in Africa. They underscore the cultural, economic, and governance diversity and institutional heterogeneity, rather than a monolithic continent. The following self-explanatory quote sums up what we are actually dealing with.

What we now increasingly do is we think much more in terms of sub-clusters, where you have East Africa, where you have West Africa, where you have southern Africa." ... Frank Braeken, the executive vice president of Unilever in Africa, said that for a long time, multinationals have thought of the vast continent as a "monolithic" market, failing to address its diversity. "The African consumer has been underestimated, underserved, and underserviced," said Braeken. "What I mean is we have looked at it a little bit generically, like 'the Africans,' a little bit patronizing generically. Now we start to take the African consumer seriously." ... "I'm almost somewhat ashamed to admit that we are still very much in learning mode about what the differences are within Africa." ... "Rather than just a continent, Africa must be viewed as 54 separate and distinct countries with a wide array of political, economic, geographical, cultural, and social features," said Nielsen's 'The Diverse People of Africa' report ... there is no 'single African consumer'. Instead, [there are] seven types of consumers [that] can be grouped in three tiers based on their monthly income and average spending. [101]

In the same vein, smaller African countries such as Gambia, Liberia, Sierra Leone, and Namibia have limited bargaining power vis-à-vis the colossal MNCs. For this reason, we cannot expect that their bargaining power can help shape what MNCs make of CSR. It is here that CSR is required when there is the need for accountability where strong institutional structures are lacking. The diverse contexts of Africa make any attempt at generalization false and misleading. Each of the 17 emerging countries in Africa is unique [69]. Nevertheless, there is an emerging consensus about their common patterns of development that are influenced by both endogenous and exogenous factors. The changing patterns of consumption and new mobility frontiers (rural-urban influx) lead to the rise of megacities and the 
exponential increase in the middle class alongside the left-behind in the rise of Africa, which portray a novel scenario worth investigating. Most importantly, WECS Africa's integration into the global market is increasing more than in any other period in recent history [102]. Therefore, as with any in other country, proper governance, taxes, rents from natural resource endowments for infrastructure, and investments in innovations that meet the needs of the nations must be prioritized, but this has been met with a perennial lack of finance.

\section{Institutional Void and Differences in CSR}

The dominant hypothesis or the textbook script is that where the institutions do not bear the inherent characteristics of Western (Euro-American) systems (efficient banking systems with legal and enforcement mechanisms), then we put zero in the equation. Or, where governance structures are weak, corporations must step in [103], even though they were not created for providing public utilities under any constitutional order. Economic agents mostly respond to owners and not citizens. A complicated way of labeling a weak governance system is "institutional void" $[23,37,104]$. This is a tragedy, but what does it mean for the manager who must practice authentic CSR, or the people within the contexts that we theorize about? This is a useful analysis, because the concept involves "institutions" and "void" or "emptiness" in the same line. This is then constantly tied to a vital need to fix, regulate, and fill. However, if we introduce the shifting contours of African contexts (geopolitical and economic blocks, the different levels of political and economic emancipation, and different forms of capitalism, such as crony, informal, or liberal), it immediately sweeps away the worn-out clichés and the colonial hangovers that establish the burden to philanthropize the responsibility for ensuring socioeconomic development rather than innovatively engaging with countries to solve the root questions based on the contextual demands $[105,106]$. Are these complete and satisfactory perspectives grounded in serious empirical evidence, just reductive explanations of a complex substantive domain, or are there some missing details in the bigger picture? There are arguments that challenge the above suppositions. It seems that what is now deemed political CSR $[24,103]$ is a conjured vocabulary of deception in a neo-colonial framework where African countries are presented both in imagery and literature as lacking institutions and essential natural and human resources for economic development. However, political CSR may well work in a refugee camp but not in a regular society. Such a governance mechanism is probably possible only after a long period of disempowerment that has led to a lack of self-sufficiency. Before any further analysis, a survey of the literature is presented on institutions and their links with CSR.

Analyses of institutions as foundations for understanding relative differences in CSR practices in different contexts abound. See, for example: Aguilera and Jackson [107]; Hoskisson, et al. [108]; Husted and Allen [109]; Jamali [5]; Namada and Bagirea [40]; and Zhao, et al. [110]. The quest for a deeper comparative understanding of institutions and CSR practices for the engineering of innovative solutions to sustainability questions is now imperative. International business and management scholars have adopted institutional theory to address country-specific or important regional issues [111-114]. Nevertheless, the CSR literature presents an interesting mixture: a cacophony or a confused collection of analyses, as well as overstated speculations alongside a clearly formulated and serious representation of theory about the African context. The studies range from empirical or conceptual analyses to general reviews and commentaries. These come from an assortment of highly regarded and well-rounded academics all the way to wannabes who pick any interesting theoretical model to explain Africa, albeit with fundamentally flawed premises. This brings up the Alvessonian question: do they have something to say [115].

The formal elegance of institutional theory is endlessly fascinating. Its analytical connections with corporate responsibility issues are intricately interwoven. It reveals the anatomy of organizations in a nuanced manner and in profound ways. It also traces social structures, as well as socio-cultural, normative, and regulatory systems that affect and are affected by organizations [116]. It provides an interesting framework with which to analyze how organizations operating in different contexts are 
shaped by not only their ecology of organizations [117], but also unseen and untouchable systems or the rules that shape human actions and interactions [118]. By its very nature, institutional theory is highly complex, and yet is able to simplify business-society issues in an interdisciplinary manner. This explains its conceptual usefulness in different subject areas. The preference for institutional theory stems from its explanatory depth conducting the scholar to an immediate awareness of how little we know about the complexity of the social world and the interactions between resources and actors. Following Scott (2014) [116], we offer reasons why institutional theory merits special attention, especially in the study of CSR. Institutional theory is a 'fit-for-purpose' framework for studying and posing provocative questions about the ways that organizations behave and work, both internally and in relation to their environment. This framework helps unravel the reasons why moral obligations are either pursued or ignored by organizations, considering the role of individual actors in enacting strategies. Further, according to Scott (2014) [116], this institutional framework also helps connect the micro and macro levels of social structures whilst linking the past and the contemporary, and acting as a tool for understanding the probable future [119]. Most importantly for our purpose, institutional theory connects multiple fields in the socio-economic sciences, allowing for a rich interdisciplinary study and understanding of social phenomena where the modern corporation's operations in marginalized communities are hugely implicated [47,55,86]. For Hofstede et al. [120], "institutions are the crystallization of culture, and culture is the substratum of institutional arrangements." Hence, any attempt to claim a causality link between the two is a useless endeavor [121]. Notwithstanding all of the above conceptualizations, institutions around the emerging and developing economies are not necessarily dysfunctional or void without enforcement mechanisms.

\section{Novelty and Purpose}

The central argument presented here is that big international business and geopolitics go hand in hand [42,44,122]. In weaker institutions, MNCs have powerful influences on regulations [123], and they profoundly shape the nature of institutions mostly to their advantage [41], and at the expense of the larger society $[34,47,86]$. The former colonial masters of Africa enlisted non-state actors to continue the "prende e scappa" (take and run away) using Africa ("Periphery") as the source for resources and the "Center" for manufacturing and refinement [32]. This study introduces the hypothesis of pluriversal polities and paradigms in explaining the irregularities and order of institutional settings. Thus, within the developing economies of Africa, there are polities and systems that are outside the parameters of the existing ontologies, cultural frame of thought, and the expectations of Western management researchers. Further, there are polities and systems across Africa that operate in parallel with Western models. It is postulated that wherever human societies exist, there are forms of organizing. These organizations are both international and local in nature [42]. They are also embedded in socio-economic, political, and cultural/religious institutions/polity $[104,124]$ that shape and are shaped by responsible or irresponsible organizational practices in both evolutionary and revolutionary ways. Nothing comes out of nothing: ex nihilis nihilis fit. It is further postulated that while market institutions may be in a constant state of change, socio-political institutions and informal systems may be very resilient to technological and other exogenous shocks.

Scholars attribute an institutional void to both market and government failures. More specifically, the lack of infrastructure, strong legal framework, enforcement mechanisms, or economic progress has led to poverty, unemployment, a high disease burden, and general economic underdevelopment [19-21,125]. This thesis is also supported in part by Kuada and Hinson [22], whose study concluded that local and international firms appear to see CSR differently. Local firms do discretionary acts because society expects that those who have more should give more. In other words, in a mostly Christian population, the idea of 'to whom much is given much is required', or acts of charity and sharing, are clearly within both African as well as Judeo-Christian tradition. Jamali [5] also offered similar examples from the Middle East and Northern Africa or Muslim countries—otherwise called Zakat (the Islamic obligation to give alms). For example, foreign firms in Ghana, according to Kuada 
and Hinson (2012) [22], engage in CSR because of legal requirements. However, truly responsible firms cannot neglect normative obligations. None of that is true CSR per se. By contrast, in Germany and Scandinavia for example, the workers' unions' ability to press home their demands is facilitated by strong legislation to ensure the well-being of employees. In this sense, only what the firm does beyond the legal requirements to provide welfare for all concerned is considered corporate responsibility, which is a far cry from giving alms. However, across Africa, the weak stakeholder constellations have meant that what is considered legally binding normal behavior in the West is labeled CSR.

"In Africa, CSR activities consist mostly of those activities that add to infrastructure or the economic development of the community through job creation [and] taxation" [126]. However, corporate tax payment is deemed a normal behavior required by law; it is not a special act. Companies hire because they require labor to make things work, and they build roads where they will need them to transport mostly raw materials with ease. In 2000, a survey conducted by the World Business Council for Sustainable Development [127] demonstrates how CSR in the neoliberal era is an attempt to fill the institutional and governance voids in developing economies. For example, when Ghanaians were asked how they think CSR should be defined, they stressed "building local capacity" and "filling in when government falls short". However, the study did not take into consideration the created quest for help from outsiders as a symptom of a dependency syndrome. The emergence of public-private partnerships and government-NGO partnerships as a way of sharing responsibility is what Whelan et al. [128] refered to as organizations acting in "civic republicanism" status. This has been the case even since the early 1970s with technical assistance, human investments, and other forms of aid, but this has not bridged the gap between the so-called developed and developing economies [65,129]. They have been useful for alleviating temporary pains, but as boutique actions, they are not in any way structurally transformational. Hence, resource-abundant nations remain constant recipients of charity.

\section{The Hypothesis of Pluriversal Polities and Paradigms}

How do we decrypt the idea of weak institutions as simply referring to weaker populations in essence? Culture, cognitive frames, regulation, mores, and associated activities and resources would mean nothing without a nation or people. In other words, weak institutions mean weak people who must be helped and/or taken advantage of. In evolutionary terms, the weak must succumb to the strong in the scramble for survival of the fittest in a Darwinian sense. All human societies have evolved over the millennia with ideas, philosophies, norms, lifestyles, traditions, arts, and ways of valuing and attaching worth to products and services, as well as written and unwritten rules governing exchange [124]. Institutions exist in all human societies. There is no vacuum. They only differ from one context to another. In fact, Jared Diamond [130] in The World Until Yesterday suggests that there is a lot to learn from traditional societies that could complement emergent social practices. Any ordinary observer from another planet could legitimately question the reason for this semantic distortion: "institutional void". The taken-for-granted assumption, which is mainly Western-centric, is that if the formal institutional structures are not fashioned in a way that allows MNCs (especially those in the extractive industry) to fit in, adaptation and transaction costs increase [131,132], and that is economically inconvenient. Therefore, MNCs declare the institutions of the host country to be a 'void' because the institutional structures are based on non-Western models. Moreover, as the more powerful actors, MNCs influence such contexts by removing or neglecting existing norms and reinstituting new norms and practices as long as they serve to manipulate the system and 'structures of accumulation'. Nevertheless, this is not done with the contextual logics and structures in mind, but rather with a framework that in the end disadvantages the already marginalized. These Western views are not improper; they are simply different to the particular African context. This causes disruption that leads to increasing friction- to which we shall return.

Institutions have a significant impact on the political economy, which refers to the relationship between economic conditions and the political choices that the citizens of a state have to make $[61,62]$. 
Contemporary scholars of institutions point to the analysis of voids in institutions (see definitions in Table 2 below).

Table 2. Definitions of institutions and their characterizations.

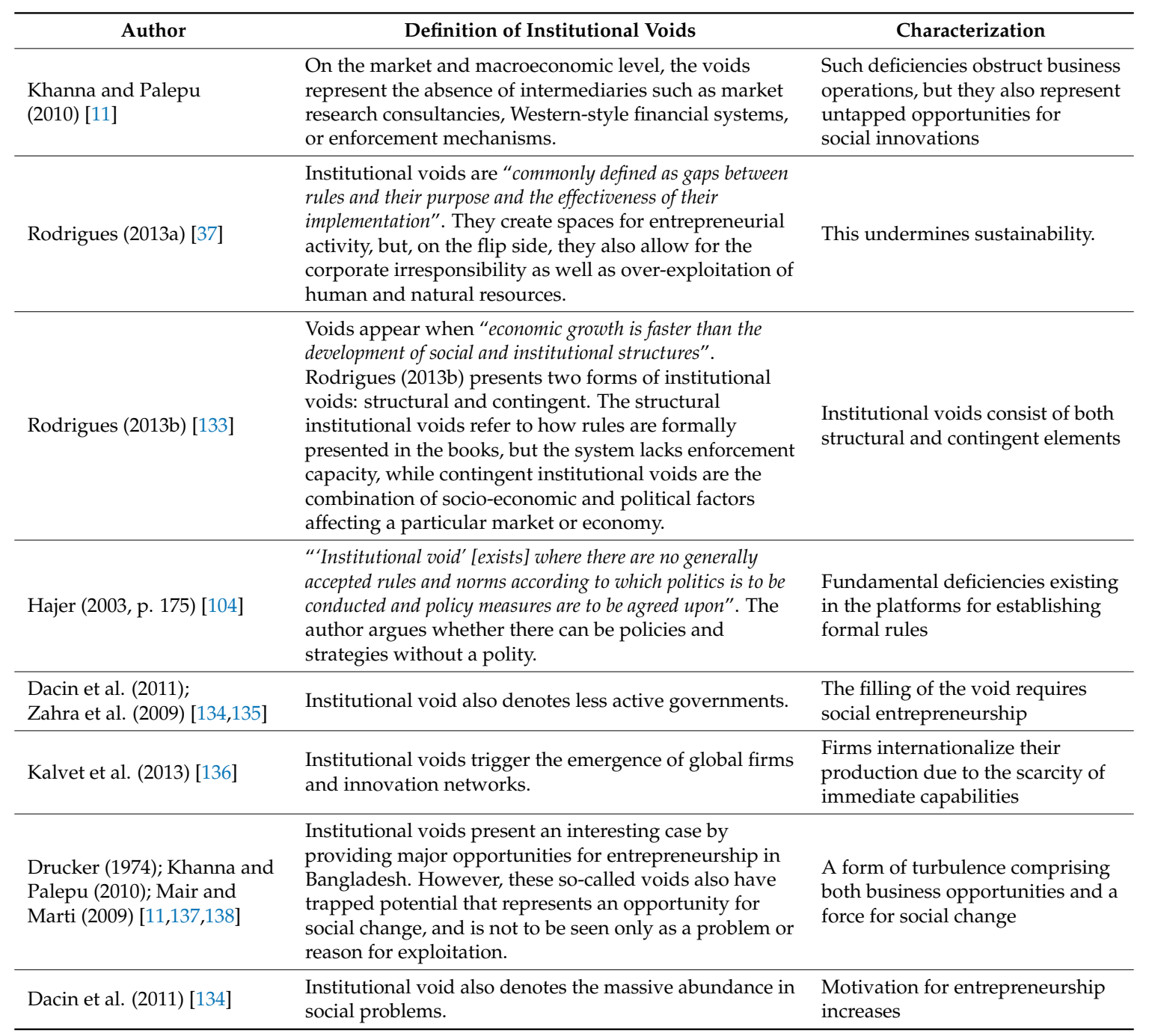

\section{Why is Philanthropy a Major Feature of Corporate Responsibility in Africa?}

That CSR in Africa must mostly be represented as, or has the image of, charity is a false equivalence that tricks students, stakeholders, and other practitioners into misdiagnosing the real ethical and environmental responsibilities, and prevents them from offering the real solutions. It is important to note that all CSR is strategic, with the end goal of meeting the corporate bottom line above anything else. What we see is an argumentum ad populum, which is obviously the result of academic hegemony [14] that passes a unidimensional view of false superior practices to future managers. This is not to suggest that Western epistemological positions are unwanted or flawed. They simply do not always produce contextual frames that are meaningful when they ignore local exigencies where they are transposed. What is more striking is that this model is not even transposed, but rather specially thought out for resource-abundant developing nations because it works as an emotional distraction. We are not suggesting that philanthropy per se is a bad idea or an unwelcome cause, in fact quite the opposite: just that it has its place. It is not a substitute to actual responsibility that solves structural socio-economic and environmental problems with new innovations due to its intermittent nature. This means that governments must commit massive resources to modernize formal structures and reduce the innovation gap. The question is, who controls those resources [56]. There is the need to 
meaningfully redefine the imposed practices and discourses of CSR that tend to invalidate local ideas and realities. Counterfactual examples of corporate charity abound. However, we are looking at the bigger picture here. At the same time, within the discourse at hand, it is a plaster to a situation that requires surgery. Philanthropy is a good deed, but it is not the best solution to structural problems. In fact, in some cases, the ways that it is practiced make it a counterproductive act in several ways. From a purely marketing perspective, it creates an image deficit for African innovations, products, and services, and even undermines the dignity of African people as the face of poverty in the world. How much is a good image worth? Advertisers and marketers know that it is worth billions and beyond because of trust, respect, and status. Additionally, such a negative image deters investors and tourists because of manufactured risks and reinforced negative images and perceptions [139,140]. Meanwhile, philanthropy campaigns steal the spotlight from local Africans (private and corporate) who are doing their best while overshadowing that remittances by fellows in the diaspora amount to more than the total amount of aid in any given year [141]. For example, the rap artist Akon co-founded the Konfidence Foundation (konfidence.org), which is a health and education charity for underprivileged children in West Africa and the United States. He also co-founded the Akon Lighting Africa project in 2014, which Akon's site says has brought solar power to 18 African countries so far (akonlightingafrica.com). There are thousands of examples more examples, both from MNCs (e.g., Coca-Cola partnering with World Vision [142]; BASF's sustainable strategy in developing economies [143]; German companies in South Africa [144]) and individuals. However, in most cases, charities tend to show the negative images and statistics, which suggest that only poverty abounds [26], even though there is a rising middle class that numbers in the millions [145]. It relieves the uncaring wealthy Africans of the responsibility to invest in Africa instead of depositing millions in secret foreign accounts.

\subsection{Emerging Proposition of Level Playing Field for Trade/Investments and the Rejection of Free Lunch}

In fact, on the aid front, the Kenyan president Uhuru Kenyatta (2015) [146] recently tweeted that:

The future of our continent cannot be left with the good graces of outside interests. Dependency on giving that only appears to be charitable must end. Foreign aid which so often carries terms and a condition that precludes progress is not an acceptable basis for prosperity and freedom. It is time to give it up.

More recently, the government of President Nana Akufo-Addo of Ghana has set up a committee to draw up a charter that will make "Ghana beyond aid" not just a mantra, but also a way to effectively collect taxes and make responsible use of the country's resources instead of depending on the good graces of others.

All of the above is because it is generally accepted across Africa that philanthropy-based CSR by some MNCs in marginalized communities is a colonizing concept $[58,147]$ that is disguised as liberation to "invisibilize" massive socio-ecological harms [25,26], while highlighting minor demonstrations of benevolence. More specifically, philanthropy is a universal way of demonstrating human compassion. It is very normal for individuals or organizations to support those in distress, promote something of social interest with resources, or give donations and relief to those in need due to a natural disaster or a temporary unfavorable socio-economic condition. However, it must be recognized that none of these is meant to be permanent. Hence, to be labeled an eternal recipient of help/aid puts a host nation or community in a position (negative branding) that does not allow it to live up to its full potential [91]. Scholarships/grants or community empowerment programs constitute investments by firms, governments, and NGOs to foster education or research that will benefit everyone in the long run, including firms [148]. They are commendable investments, not costs. Clearly, firms exist to economize on transaction costs. Then, in the light of the efficiency thesis, giving corporate cash or kind is not an efficiency driver unless it is an offensive or defensive act for earning legitimacy [149]. It must serve some strategic purpose. CSR is a socio-economic, political, and environmental obligation that 
demands accountability from organizational actions and the use of scarce resources. All of that must have an ethical foundation [4].

Is it possible, then, that communities in weaker institutions accept philanthropy as a substitute for genuine sustainability-oriented CSR because they lack any bargaining power or choice and have no stake that empowers them to press home their demands [150]. Are these arguments convincing, or are there layers of understanding that are yet to be explored? The points below are not to be interpreted as anti-philanthropy, but rather a way of shedding light on the manipulation based on a system that tricks stakeholders into believing in the benevolence of the powerful, who give with one hand and take more with the other. This much is held as a secret from the good rich people in industrialized nations who give willingly in the hope of changing others' lives, but for some on the other side, this is just a business.

\subsection{Interrogating the Sustainability of Philanthropized Corporate Responsibility}

First, given the institutional heterogeneities, compressed forms of development [42], and national business systems across Africa, the emphasis on charity as a form of CSR, not as an aberration but a norm, in different African nations may be hiding something about the environmental degradation, land grabbing, and dispossession $[49,69,73,151]$. Therefore, leaving such false assumptions by academics and practitioners unchallenged may constitute an irresponsible legitimization of corporate malpractices and endorsement of misleading vocabularies of motive that deviate wholly from the optimal societal expectations of sincere CSR $[10,48]$. At the same time, there is a growing number of boutique projects that are seen as simply legitimating tactics [71]. This is because in most cases, CSR is either a defensive or offensive strategy [152], notwithstanding the amount of evidence that putting socio-economic and environmental value creation first yields better results than putting stockholder value creation first [106,153].

Second, this hypothesis assumes that MNCs' CSR practices in host countries must be exceptionally different because of perceived poverty, despite resource abundance. In home countries, the practice involves an innovation-focused strategy (over the long term) [27], whilst in host countries, it is about philanthropy (short-term relief). As an example of governments' green growth initiatives in the West, see Shirley (2016) [154] for government support of "environmental protection along with economic growth where Denmark has pledged 13.5 billion Danish krone (approximately US\$1.9 billion) to its Green Growth initiative". That means Denmark, similar to all of its Nordic neighbors, who rank among the highest in the Sustainability Index, would not need a foreign firm to come and take care of their environment. Third, some authors have argued that although philanthropy is commendable, similar to aid, it is unsustainable and creates dependence and complacency [91], and has little to do with effective CSR in action to bring about structural-institutional change. Fourth, philanthropy-based CSR clouds the intractable problems resulting from corporate externalities, whilst offering simplistic and ad hoc solutions through one-way transfer instead of stakeholder engagement $[138,155]$. At first glance, philanthropy in the public eye is the optimal response to filling the institutional voids and gaining legitimacy. However, it is neither sufficient nor necessary for the sustainability imperative in the long term.

It follows in the fifth point that philanthropy by corporations is in vogue in weaker institutions, but less so in the West. Nevertheless, philanthropy hardly produces the needed structural change due to its unsustainable and ad hoc nature. Economies do not develop through handouts $[90,91,156]$; they develop through responsible innovations where both private and public sectors take full responsibility for their day-to-day actions beyond the legal requirements to improve welfare and bring about change. Ethical behavior then represents obedience beyond legal requirements or the enforceable with the value chains of material extraction and human resource.

In addition, critics have argued that in weaker institutions, philanthropy-focused CSR creates dependency, forces governments to abdicate responsibility to corporations $[4,34,157]$, and disempowers stakeholders due to the lack of quid pro quo. Thus, unsustainable aid and philanthropy outside 
situations of emergency are disempowering mechanisms for achieving economic development. The neglected voices at the margins only sporadically receive cash and kind in the form of charity. However, as Moseley [158] put it, "It's insulting [morally degrading] to be classified as an object of charity. Worse yet, the charity model may disempower local people by convincing them that they are somehow inferior." In fact, ethicists and economists share this view [6,91]. More disturbingly, Chiminazzo [159] argued that within the markets and economics of the era of globalization, philanthropy gives nothing new, but rather only translates into momentary satisfaction. It requires back a condition of permanent gratitude, if not the inferiority of its receivers. A famous quote by the civil rights pioneer Dr. Martin Luther King sums this argument up perfectly: "philanthropy is commendable". However, it "must not cause the philanthropist to overlook the circumstances of economic injustice which make philanthropy necessary" [in the first place] (emphasis added).

Furthermore, this way of pitying is not an accidental practice. It is a well-designed approach of negatively branding the 'Others' (putting them in their place) that makes all products with the country of origin from Africa easily considered inferior $[160,161]$ and purchased by kind people just to help those who cannot help themselves. However, such products are not purchased for their quality or prestige. This enormously reduces the competitiveness of African products. Such systems as they are perpetuated go to the point that people of the African continent are treated as inferior people in international trade negotiations [122]. They are always shortchanged, and their interests matter less most of the time [162,163].

More so, the fundamental reason why CSR in Africa cannot and must not be based on a reductionist thinking that simplifies everything into philanthropy is our common pool resources [164]. Socio-economic, political, or environmental irresponsibility under the watchful eyes of complicit or co-conspiring governments anywhere affects everyone everywhere because of the global interconnectedness and interdependence. Hence, global warming as well as environmental, air, and water pollution caused by big firms are not to be treated as distant issues that require philanthropy in order to be solved. They require actual action to prevent them. This means that a concerted effort is needed in which the bearers of major responsibility are identified and made accountable for taking so much and willing to give so little or nothing back [74]. Further, one cannot reduce the needed CSR discourse to a mere philanthropic gesture, especially in times such as these where global uncertainties abound. This is because poverty and economic under-development are symptoms of much broader and deeper geopolitical, international, and political economy factors. Together, these factors have a long history of abuses and structural forms of inequality [165]. In synthesis, MNCs have socio-political, environmental, economic, and ethical responsibility everywhere, every time, in all day-to-day activities. Philanthropy is not the main function of a business entity; philanthropy is a discretionary activity. Therefore, that firms' donations are labeled as CSR does not necessary mean that they indeed constitute CSR, unless such an action is a proactive integration of corporate responsibility and socially useful (ethically acceptable) innovations into corporate strategy, i.e., strategic corporate responsibility [155] that intentionally avoids harm. To this end, it is argued that doing "free giveaways" is not CSR, only because firms have chosen to label it with such a nomenclature to describe something that is nothing more than a legitimating tactic [166]. On the other hand, sustainability issues arise where MNCs operate with impunity and with unrivaled corporate political power $[47,48,157]$, slave labor [167], and the pursuit of vices through the use of corporate political power [168] and total institutions [169]. A total institution has been defined as an organization that has more or less monopoly of its members' everyday life [170]; see also Goffman [171]. Taking responsibility for an oil spill or environmental degradation is one thing, and giving gifts to community schools is another. Philanthropic actions have moved from being a mere PR tactic to removing governance and regulatory power from the collective to the individual $[71,157]$. Such a situation is dangerous, because it fails to address the fundamental problems that undermine democracy $[2,43]$ in the host country. However, the gravity of this depends on the degree of weakness of the country's institutions. 
More disturbingly, paltry attempts by big corporations to appease local communities after environmental degradation have now become a staple in the playbook of how to calm down angry protests by environmentalists. These include media campaigns and philanthropic gestures for face-saving, which are temporary solutions to emerging health and environmental questions. These oversimplified solutions lead us to the next important point. If CR is viewed as the sum total of the whole investment and the resulting products, then philanthropy is a big trick that has deceptively worked for a long time, because it ignores all the following: (i) the physiological condition of the natural environment where resources are taken; (ii) the conditions of the human resources employed in transforming raw materials (manufacturing process using child labor or dangerous working conditions), of which the textile industry is an example; (iii) the environmental footprint of extractivism, transportation, and distribution; (iv) the safety of products and their ethical use; and (v) the responsible final disposal of the consumed products back into the environment. For example, African countries have for long served as the dumping ground for electronic and other forms of waste [172]. This flaw in making philanthropy a corporate resource in Africa removes any idea of a sustainable design and green technologies as an imperative of sustainable CR actions. Philanthropy in its nature obscures the negative elements of globalization, neoliberal capitalism, and the authoritarian systems that manifest themselves in global agenda-setting, decision-making, and regulations [173]. These include land grabbing and other neo-extractive approaches of development [25]. Charity or philanthropy does not do away with trade distortion policies such as protectionism disguised as hygiene protection, or dumping that kills local industries [174]. Philanthropy then obscures key emerging issues such as robotization and the automation of production, resulting in fewer jobs for people. The next point that makes our case here is donor fatigue, especially in the current economic climate. In fact, emerging economic problems reveal how unsustainable dependency is.

More to the point, the images of the poor around the world tend to suggest that no one from their communities is helping; they are stuck with their portion in life, and that is the way it is. Nothing could be farther from the truth. Across the developing world, there are several local NGOs who do their best to bring change (sometimes in collaboration with international NGOs) without jeopardizing the image of the people, and they deserve more credit than they are receiving. We agree that there are countries or communities that need help sometimes. However, when that becomes permanent, then we are rather treating them as mentally handicapped people who cannot help themselves instead of asking how the problem came about in the first place. This will be making the case for Lynn and Vanhanen [175], who argued that the mentally weak, or more precisely, those with a biological predisposition to have low IQ must be helped as a moral duty. Therefore, it is the white man's burden to clothe and feed Africa after civilizing it [90]. The relevant question is: how do Africans want to see themselves?

The final and most prominent case against philanthropy as a substitute for responsible behavior is that philanthropy sounds eerily atrocious and manipulative in the ears of every conscious African, and for a good reason: there is no free lunch, and they know. The question that remains is: this free lunch is in exchange for how much of what? History offers some noteworthy answers. Colonialists who "owned" the Congo and its people and resources massacred millions of Africans, but this horrible genocide was presented to the people of Europe as a "philanthropic" and "scientific" operation by a humanitarian and under the guise of the International African Society [176]. The enslaved labor force helped extract resources (rubber) controlled by a private army that mutilated hands, and tortured and killed millions [176]. Even the author Mark Twain and the Archbishop of Canterbury participated in human rights activism along with many young European and Americans who risked their lives to expose this tragedy. What is interesting is that the survivors of other atrocities received massive sums of money as reparations, but Africans have not. Today, the underpricing of resources, non-payment of taxes, mega-corruption through shell companies, and corporate land-grabbing [78,177], as well as management by dispossession, are leaving millions displaced and in poverty $[74,86]$.

The current PR-style philanthropy as a solution to deep-seated structural problems distracts from the root question as to how we got here in the first place. Such a practice also distorts the noble image 
of humanitarian actors, because it makes it difficult to distinguish between those with genuine motives and those who are using it as a diversionary non-market strategy to hide exploitation. Furthermore, it is a practice in which philanthropists imagine the beneficiaries as passive actors who eternally need help.

On the NGO side, Fred Branson [178] in his TEDx talk argued that using pity to raise funds as the key currency in exchange for the dignity of others is not only demeaning, it is also unjust:

While organizations may gain in funds, poor communities will lose in dignity, empowerment, and voice. These communities care about their appearance and how they are portrayed. Further, pity is not only unfair to the people who are being portrayed in a campaign, but it actually distorts our perception of life in developing countries.

Such relationships expose an implicit hierarchy within them. While much of the money that is raised is unaccounted for, such portrayals lead us to ignore the potential in such people and communities. Acting in pity leads us to "turn humans into passive victims deserving of our pity [but not respect]. We dehumanize them. We promote the idea that communities don't have the capacity to solve their own problems, and that it's we in the West who must single-handedly device the solutions" (ibid.). A good example is the numerous NGOs operating in Northern Ghana. They grow in size and budget, but the population gets poorer. Sociologist Alhaji Mohammed Saani described these NGOs as "giving someone something with your left hand and taking it back with your right hand" [156].

Additionally, there is more on the accountability side of the issue. In fact, the first groups that countries want to ban are NGOs when there is a conflict, because it has also become the very group in which it is easy to infiltrate under the cloak of philanthropy. Religious groups give cash for socially useful agendas and think they have given to the Lord in good faith and trust of the NGO operators. Yet, they mostly demand no accountability. Most of the time, it is simply a matter of massaging their own ego by paying the price of appearing good in their own eyes. One could imagine what kind of a world it would be if a small percentage of givers would randomly question NGOs about how their money is spent [179]. Some NGOs are among the most opaque organizations, and since there are too many NGOs, they employ a guerrilla marketing style: thus, the gorier the images, the greater the pity, and therefore the good people of the West will respond and the cash flows. The problem at the heart of this is that philanthropy is an ever-flourishing industry and part and parcel of the global governance structure where the periphery will have to depend on others for survival.

In what follows, we posit that instead of oversimplifying the CSR discourse by lumping all philanthropy together, we can classify organizational philanthropy (at least in theory) into five archetypes which are all either defensive or offensive strategies, with the exception of the last type:

(i) Transformational philanthropy: eradicating unfavourable initial conditions by targeting underdevelopment and establishing innovative changes, e.g., scholarships, grants for research and innovation, seed funds for entrepreneurs, 'Marshall Plans' (massive amounts of money from the US to Germany after the WWII).

(ii) Boutique philanthropy: mainly a legitimating tactic to hide or divert attention from insidious acts or as a damage control.

(iii) Status quo philanthropy: aims at maintaining the original conditions that necessitated help in the first place. For example, supporting projects that give legitimacy for the continual presence of firms in controversial extractive deals or military operations with a human face but maintain continued exploitation (e.g., via lobbying powerful people and governments).

(iv) Soothing philanthropy: temporarily helping those that are affected by unpredictable circumstances (e.g., hurricanes, floods, fires, earthquakes) in order to gain PR points but also as a genuine act to support local communities. It does not stop the hurricanes or possible weather modification programs, or in case of city floods, it does not question constructions on water ways.

(v) Natural philanthropy (intra-human duty of care): is the 'Mother Theresa' type of genuine charity by rich or less wealthy persons (sometimes even anonymous), churches or non-highly 
bureaucratic NGOs, or individuals with a calling, assisting individuals, e.g., children, aged or physically challenged who may not ever be able to fend for themselves. Notice that this is the genuine philanthropy that asks nothing back.

Beyond the above theoretical classification, there are a couple of interesting paradoxes worth mentioning in the current global philanthropy landscape. There are ultra-wealthy Africans who ignore the serious socioeconomic problems in their home countries and rather deposit billions abroad and seek medical care abroad instead of building hospitals at home [26]. Then there are rich Hollywood stars traveling to Africa to take pictures with the poor while leaving the thousands of poor and homeless in the US. This has now been called the 'White savior's syndrome' as part of the White man's burden [90]. While we applaud some genuine individual and corporate philanthropic initiatives, attention must now be directed towards a global effort to prevent resource exploitation and financial outflow from Africa.

\section{Conclusions and Discussion}

This study answers the question: how do institutional voids account for the varieties of CSR practices across Africa that differ from Western CSR practices? Moreover, the study investigated the follow-up problem: is it possible then that communities in weaker institutions accept philanthropy as a substitute for genuine sustainability-oriented CSR because they lack any bargaining power or choice to press home their demands?

Corporate responsibility can be truly conceptualized as investments that can be analyzed in all of their ethical, socio-economic, political, environmental, and sustainability components, in order to create the maximum social value in a world of scarce resources by all of the major actors. Despite this general understanding, CSR in Africa has philanthropy as its centerpiece. The argument that CSR has no common definition is partly necessary and partly unnecessary. It is necessary because it allows for a single theoretical framework within which to work. It will create a more generalized understanding. On the other hand, it is unnecessary because it is a dynamic concept that is constrained and enabled by institutions and contextual circumstances. Therefore, a fixed meaning is unhelpful, because it will require the standardization of organizational actions everywhere, but such a situation will not foster innovative differentiation that serves local needs.

\subsection{Contributions to the Literature}

The novelty of this study is that it emphasizes the existence of local polities and paradigms to explain that there is no such a thing as institutional void per se, but there is an institutional difference outside the paradigm of expectation (well-functioning market and intermediary systems and enforcement mechanisms as originally intended [11]). This means that the existing paradigm of fixing so-called voids with philanthropy must be interrogated, given its regressive nature and diversionary approach to the core issues. Therefore, policies and strategies must adapt to the evolutionary dynamics of the context in the quest to answer the questions of famine, disease, and poverty that firms or governments may have contributed to creating in the first place. The implications of the results are vast, and they are generalizable to all of the weaker institutional settings. We argue that weak institutions create the necessary political and economic climate that perpetuates a pattern of abuses and ethical violations. Thus, strong institutions help host nations to press home their demands and not get short-changed with philanthropy. The uniqueness of this study is that it revitalizes the debate on CSR through a dialectic approach that compares one well-studied setting (industrialized nations) with another less explored context (Africa).

The answer to the second question is that weaker institutions clearly lack the bargaining power to press home what is naturally theirs. Therefore, they accept philanthropy in place of higher expectations such as investments in cutting-edge innovations that can contribute to structural changes as in the West. The root of this is weakened democracy vis-à-vis the dominion of corporations practicing voluntary goodness [43,47]. In the West, agriculture, technological innovation, and science are promoted with 
public subsidies in the quest to ameliorate well-being [163]. Across the various economies of Africa, in most cases, corporations ship profits back to the home countries $[180,181]$ rather than reinvest to expand the business and create employment and knowledge transfer in host countries. This reinforces the rent-seeking behavior. It would not be preposterous to suggest that since colonialism, there has been a political necessity to create a begging group in the global economic system in the periphery in order to maintain the status quo and the dominant role of the powerful MNCs [32,58]. This makes even more sense in light of Shamir's [157] argument about the corporatization of politics and the moralization of the markets.

Thus, there is a German, Japanese, or a Chinese approach to CSR, but there is no such thing as an African approach to CSR. There is not even a regional approach, because of the different levels of institutional maturity. However, what has become a pattern is the use of philanthropy to substitute genuine corporate responsibility across Africa. This reason is because whereas the former nations are totally influenced by the strong internal politics and institutions of the host countries, the latter are influenced by the strong external geopolitical influences in all of their industrial compositions. Thus, strong institutions translate into strong bargaining power, and weaker institutions enable corporate irresponsibility to thrive as in economic Darwinism. An enduring curtain of protectionism disguised as free trade [163] leads to misplaced solutions such as philanthropy. The corrosive power of some corporations has an invisible hand that influences politics, thereby producing policies that derail positive change [47], especially in extractive industries. This latter scenario is possible because governments are weak, and are therefore complicit in the types of negative outcomes that are produced within the institutional framework. In other words, CSR is what the powerful make it to be. Therefore, what it appears to be and what it really is are always in conflict. Consider these problems, which have thus far been brazenly glossed over because of the institutional void hypothesis.

\subsection{Practical and Policy Implications}

Diversion from the original question of economic development is not an insignificant problem, because it is the root cause of all that is now being reacted to with political CSR. As with errors of navigation, pilots and ship captains would be the first to admit that minor deviations can bring about unimaginable damage with vast implications. This also applies to economic decision and policies enacted by organizations and governments. Much of what is seen as humanitarian or charitable gestures sometimes betrays both private and public actors' true intentions when scrutiny sheds light on corporate externalities (social and environmental costs).

Notwithstanding their pervasive influence, the material strategies for a change can be quite straightforward:

- If liberalization has led to big businesses' takeover of natural resources and markets [182] through forced privatization, and control of international and national regulations, the solution is clearly neither philanthropy nor fair trade products, but rather strong opposition and countervailing power (democracy) by nations to oppose such unfairness at the World Trade Organization, whilst promoting intra-regional trade across Africa.

- If the problem is poverty alleviation and economic development where there is a lack of proper health care systems and other forms of infrastructure, the solution may lie in part in the multinationals employing locals, using local content, paying taxes, and doing things right (being environmentally conscious through processes and designs) as they would in the home country-it is just morally right, it is not 'we are helping them'.

- If the problem is the so-called "institutional void" in the form of a lack of enforcement mechanisms and fast-track judicial systems, then second-best institutional approaches are always needed [183] where relational approaches work well to reduce transaction costs. Thus, promoting civic participation in democracy will also ensure equitable resource distribution. Therefore, philanthropy has its place, but clearly not as a substitute for genuine corporate responsibility, since that creates dependency and under-development in the long run. 
Woodson [184] argues that:

History shows that it does not matter who is in power or what revolutionary forces take over the government, those who have not learned to do for themselves and have to depend solely on others never obtain any more rights or privileges in the end than they had in the beginning.

Accordingly, philanthropy as a substitute for genuine responsible organizing is not the way forward. Further, it is becoming apparent that the idea of philanthropy is clearly not an investment, but is rather a cost that is aimed at removing attention away from the main problem, which is corporate irresponsibility $[10,86]$. One could simply ask that if there are these deep institutional voids, for example in infrastructure and enforcement mechanisms, why does the government lack the finances to provide for that? There is the need for an ever-deepening discovery of what ideal CSR must be.

\subsection{Limitations and Suggestions for Further Research}

Notwithstanding the important theoretical and managerial implications, there is room for more additions beyond what has been espoused here. First of all, it is beyond the scope of a single journal article to articulate in full the various impacts of the 'philanthropization' of organizational responsibility toward society and its environment. As such, future studies that widen the vista by digging deeper into the effects of philanthropy-based CSR on local communities will be a step in the right direction. Studies that demonstrate the extent to which gory images of the poor in philanthropy advertisements affect nation-branding, the country of origin of products, as well as economic development are encouraged. Moreover, studies that challenge this paper by systematically addressing how philanthropy has brought about structural changes in the long-term as opposed to sustainable practices and investments in green innovations are more than welcome. Most importantly, studies that look at new trade deals between WECS Africa and the West (e.g., EU and West Africa) [185] will help understand the changing paradigm from philanthropy and aid to serious business $[92,146,186]$.

Author Contributions: F.A. conceived the study and wrote the manuscript. J.A.-A. offered critical comments and participated in writing the manuscript.

Funding: This research received no external funding.

Acknowledgments: We deeply appreciate the comments of colleagues and anonymous reviewers that helped in refining this paper.

Conflicts of Interest: The authors declare that there are no conflicts of interest.

\section{References}

1. Snider, J.; Hill, R.P.; Martin, D. Corporate social responsibility in the 21st century: A view from the world's most successful firms. J. Bus. Ethics 2003, 48, 175-187. [CrossRef]

2. Ahen, F. Dystopic Prospects of Global Health and Ecological Governance: Whither the Eco-CentricHumanistic CSR of Firms? Hum. Manag. J. 2018, 1-22. [CrossRef]

3. United Nations (UN). Transforming Our World: The 2030 Agenda for Sustainable Development. In Resolution Adopted by the General Assembly on 25 September 2015; United Nations: Washington, DC, USA, 2015.

4. Ahen, F.; Zettinig, P. Critical perspectives on strategic CSR: What is sustainable value co-creation orientation? Crit. Perspect. Int. Bus. 2015, 11, 92-109. [CrossRef]

5. Jamali, D. CSR in developing countries through an institutional lens. In Corporate Social Responsibility and Sustainability: Emerging Trends in Developing Economies (Critical Studies on Corporate Responsibility, Governance and Sustainability); Eweje, G., Ed.; Emerald Group Publishing Limited: Beck Lane, UK, 2014; Volume 8, pp. 21-44.

6. Ahen, F. Strategic Corporate Responsibility Orientation for Sustainable Global Health Governance: Pharmaceutical Value Co-Protection in Transitioning Economies. Ph.D. Thesis, University of Turku, Turku, Finland, 2015. 
7. Ghauri, P.N.; Buckley, P.J. Globalization and the end of competition: A critical review of rent-seeking multinationals. In Critical Perspectives on Internationalization; Havila, V., Forsgren, M., Håkansson, H., Eds.; Pergamon Press: Oxford, UK, 2002; pp. 7-28.

8. Hymer, S.H. The International Operations of National Firms: A Study of Direct Foreign Investment; MIT Press: Cambridge, MA, USA, 1960.

9. Ietto-Gillies, G. Hymer, the nation-state and the determinants of multinational corporations' activities. Contrib. Political Econ. 2002, 21, 43-54. [CrossRef]

10. Banerjee, S.B. Corporate Social Responsibility: The Good, the Bad and the Ugly; Edward Elgar Publishing: Cheltenham, UK, 2007.

11. Khanna, T.; Palepu, K. Winning in the Emerging Economies. A Road Map for Strategy and Execution; Harvard Business Press: Cambridge, MA, USA, 2010.

12. Durepos, G.; Prasad, A.; Villanueva, C.E. How might we study international business to account for marginalized subjects? Turning to practice and situating knowledges. Crit. Perspect. Int. Bus. 2016, 12, 306-314. [CrossRef]

13. Jackson, T. Management studies from Africa: A cross-cultural critique. Afr. J. Manag. 2015, 1, 78-88. [CrossRef]

14. Srikantia, J. The Structural Violence of Globalization. Crit. Perspect. Int. Bus. 2016, 12, 222-258. [CrossRef]

15. Prasad, A.; Durepos, G. From margin to center: Listening to silenced subjectivities in international business. Crit. Perspect. Int. Bus. 2016, 12, 218-221. [CrossRef]

16. Carroll, A.B. A three-dimensional conceptual model of corporate performance. Acad. Manag. Rev. 1979, 4, 497-505. [CrossRef]

17. Frederick, W.C. From CSR1 to CSR2 the maturing of business-and-society thought. Bus. Soc. 1994, 33, 150-164. [CrossRef]

18. McWilliams, A.; Siegel, D. Corporate social responsibility: A theory of the firm perspective. Acad. Manag. Rev. 2001, 26, 117-127. [CrossRef]

19. Jamali, D.; Neville, B. Convergence versus divergence of CSR in developing countries: An embedded multi-layered institutional lens. J. Bus. Ethics 2011, 102, 599-621. [CrossRef]

20. Visser, W. Research on corporate citizenship in Africa: A ten-year review (1995-2005). In Corporate Citizenship in Africa: Lessons from the Past; Paths to the Future; Visser, W., McIntosh, M., Middleton, C., Eds.; Greenleaf Publishing: Sheffield, UK, 2006; pp. 18-28.

21. Visser, W. CSR in developing countries. In The Oxford Handbook of Corporate Social Responsibility; Crane, A., McWilliams, A., Matten, D., Moon, J., Siegel, D.S., Eds.; Oxford University Press: Oxford, UK, 2008; pp. 473-499.

22. Kuada, J.; Hinson, R.E. Corporate social responsibility (CSR) practices of foreign and local companies in Ghana. Thunderbird Int. Bus. Rev. 2012, 54, 521-536. [CrossRef]

23. Tyler, R. Business must fill voids in emerging market nations. The Telegraph, 26 June 2010.

24. Scherer, A.G.; Palazzo, G. Toward a political conception of corporate responsibility: Business and society seen from a Habermasian perspective. Acad. Manag. Rev. 2007, 32, 1096-1120. [CrossRef]

25. Acosta, A. Extractivism and neoextractivism: Two sides of the same curse. Beyond Dev. 2013, 61, 61-86.

26. Dearden, N. Africa is not poor, we are stealing its wealth: It's time to change the way we talk and think about Africa. AlJazeera.com, 24 May 2017.

27. Strand, R.; Freeman, R.E.; Hockerts, K. Corporate social responsibility and sustainability in Scandinavia: An overview. J. Bus. Ethics 2015, 127, 1-15. [CrossRef]

28. Benon-be-isan Nyuur, R.; Ofori, D.F.; Debrah, Y. Corporate social responsibility in Sub-Saharan Africa: Hindering and supporting factors. Afr. J. Econ. Manag. Stud. 2014, 5, 93-113. [CrossRef]

29. Burgis, T. The Looting Machine: Warlords, Oligarchs, Corporations, Smugglers, and the Theft of Africa's Wealth; William Collins: London, UK, 2015.

30. De Jonge, A. Transnational corporations and international law: Bringing TNCs out of the accountability vacuum. Crit. Perspect. Int. Bus. 2011, 7, 66-89. [CrossRef]

31. Köhler, H. Von der Unmöglichkeit über Afrika zu Sprechen. Available online: http:/ /www.horstkoehler.de/ reden-texte/von-der-unmoeglichkeit-ueber-afrika-zu-sprechen/ (accessed on 18 March 2014).

32. Galtung, J. Violence, peace, and peace research. J. Peace Res. 1969, 6, 167-191. [CrossRef] 
33. King, N.B. Security, disease, commerce: Ideologies of postcolonial global health. Soc. Stud. Sci. 2002, 32, 763-789. [CrossRef]

34. Banerjee, S.B.; Prasad, A. Introduction to the special issue on "Critical reflections on management and organizations: A postcolonial perspective". Crit. Perspect. Int. Bus. 2008, 4, 90-98. [CrossRef]

35. Longino, H.E. Science as Social Knowledge: Values and Objectivity in scientific Inquiry; Princeton University Press: Princeton, NJ, USA, 1990.

36. Becker, H.S. Tricks of the Trade: How to Think about Your Research While You're Doing It; University of Chicago Press: Chicago, IL, USA, 2008.

37. Rodrigues, S. Understanding Emerging Markets: Institutional Voids from One-Sided Economic View. Available online: http:/ / www.rsm.nl/about-rsm/news/detail/2937-understanding-emerging-marketsinstitutional-voids-from-one-sided-economic-view / (accessed on 30 May 2014).

38. Amankwah-Amoah, J.; Debrah, Y.; Nuertey, D. Institutional Legitimacy, Cross-Border Trade and Institutional Voids: Insights from the Cocoa Industry in Ghana. J. Rural Stud. 2018, 58, 136-145. [CrossRef]

39. Detomasi, D.A. The political roots of corporate social responsibility. J. Bus. Ethics 2008, 82, 807-819. [CrossRef]

40. Namada, J.M.; Bagirea, V. Management theory, research and practice for sustainable development in Africa: A commentary from a practitioner's perspective. Afr. J. Manag. 2015, 1, 99-108.

41. Campbell, B. Corporate Social Responsibility and development in Africa: Redefining the roles and responsibilities of public and private actors in the mining sector. Resour. Policy 2012, 37, 138-143. [CrossRef]

42. Ahen, F. Bow down all 7 billion: The compressed spheres of global governance. Foresight 2015, 17, $143-160$. [CrossRef]

43. Hamm, B. The end of democracy as we knew it. Foresight 2015, 17, 161-193. [CrossRef]

44. Carlson, N. Back in 2000, the CIA made these predictions for 2015. Business Insider Singapore, 1 January 2015.

45. Lock, I.; Seele, P. Politicized CSR: How Corporate Political Activity (mis-) Uses Political CSR. J. Public Aff. 2017. [CrossRef]

46. Fooks, G.; Gilmore, A.; Collin, J.; Holden, C.; Lee, K. The limits of corporate social responsibility: Techniques of neutralization, stakeholder management and political CSR. J. Bus. Ethics 2013, 112, 283-299. [CrossRef] [PubMed]

47. Barley, S.R. Corporations, democracy, and the public good. J. Manag. Inq. 2007, 16, 201-215. [CrossRef]

48. Sukhdev, P. Corporation 2020: Transforming Business for Tomorrow's World; Island Press: Washington, DC, USA, 2012.

49. McMichael, P. The land grab and corporate food regime restructuring. J. Peasant Stud. 2012, 39, 681-701. [CrossRef]

50. Epstein, E.M. The Corporation in American Politics; Prentice-Hall: Englewood Cliffs, NJ, USA, 1969.

51. Dunlap, R.E.; McCright, A.M. Organized climate change denial. In The Oxford Handbook of Climate Change and Society; Dryzek, J.S., Norgaard, R.B., Schlosberg, D., Eds.; Oxford University Press: Oxford, UK, 2011; pp. 144-160.

52. Jensen, M.C. Value maximization, stakeholder theory, and the corporate objective function. Bus. Ethics Q. 2002, 12, 235-256. [CrossRef]

53. Levitt, T. The dangers of social responsibility. Harv. Bus. Rev. 1958, 36, 41-50.

54. Sternberg, E. Just Business: Business Ethics in Action; Little, Brown \& Co: London, UK, 1994.

55. Scherer, A.G.; Palazzo, G.; Baumann, D. Global rules and private actors: Toward a new role of the transnational corporation in global governance. Bus. Ethics Q. 2006, 16, 505-532. [CrossRef]

56. Bougrine, H. Oil: Profits of the chain keepers. Int. J. Political Econ. 2006, 35, 35-53. [CrossRef]

57. Jackson, T.; Louw, L.; Zhao, S.; Boojihawon, R.; Fang, T. Chinese organizations in Sub-Saharan Africa: New dynamics, new synergies. AIB Insights 2014, 14, 11-15.

58. Banerjee, S.B.; Chio, V.C.M.; Mir, R. Organizations, Markets and Imperial Formations: Towards an Anthropology of Globalization; Edward Elgar Publishing: Cheltenham, UK, 2009.

59. Nkomazana, F. Livingstone's ideas of Christianity, commerce and civilization. Botsw. J. Afr. Stud. 1998, 12, $44-57$.

60. Harvey, D. A Companion to Marx's Capital; Verso Books: London, UK, 2010.

61. Kraus, J. Political party failures and political responses in Ghana. In When Parties Fail: Emerging Alternative Organizations; Lawson, K., Merkl, P.H., Eds.; Princeton University Press: Princeton, NJ, USA, 2014.

62. Adedeji, A. (Ed.) Africa within the World: Beyond Dispossession and Dependence; Zed Books: London, UK, 1993. 
63. Campbell, J.L. Institutional analysis and the paradox of corporate social responsibility. Am. Behav. Sci. 2006, 49, 925-938. [CrossRef]

64. Hall, P.A.; Soskice, D.W. Varieties of Capitalism: The Institutional Foundations of Comparative Advantage; Oxford University Press: New York, NY, USA, 2001.

65. Wallerstein, I. A world-system perspective on the social sciences. Br. J. Sociol. 1976, 27, 343-352. [CrossRef]

66. Piketty, T. Capital in the 21st Century; Belknap Press: Cambridge, MA, USA, 2014.

67. Zakaria, F. The 'defining challenge' of helping the poor. The Washington Post, 19 December 2013.

68. ISTAT. Poverty in Italy. Available online: https://www.istat.it/en/archivio/217653 (accessed on 26 June 2018).

69. Radelet, S. Emerging Africa: How 17 Countries Are Leading The Way; Center for Global Development: Washington, DC, USA, 2010.

70. Von Glinow, M.A. Let us speak for those who cannot. Acad. Manag. J. 2005, 48, 983-985. [CrossRef]

71. Hanlon, G.; Fleming, P. Updating the critical perspective on corporate social responsibility. Sociol. Compass 2009, 3, 937-948. [CrossRef]

72. Harvey, D. Neoliberalism: A Brief History; Oxford University Press: Oxford, UK, 2005.

73. White, B.; Borras, S.M., Jr.; Hall, R.; Scoones, I.; Wolford, W. The new enclosures: Critical perspectives on corporate land deals. J. Peasant Stud. 2012, 39, 619-647. [CrossRef]

74. Curtis, M.; Jones, T. Honest Accounts 2017: How the World Profits from Africa's Wealth; Global Justice Now: London, UK, 2017.

75. BusinessWire. Africa Wealth Report 2016-Research and Markets. Available online: https://www. businesswire.com/news/home/20160315005977/en/Africa-Wealth-Report-2016---Research-Markets (accessed on 21 June 2018).

76. Forbes. Africa's Billionaires. Available online: https://www.forbes.com/africa-billionaires/list/\#tab:overall (accessed on 22 June 2018).

77. Zucman, G. Taxing across borders: Tracking personal wealth and corporate profits. J. Econ. Perspect. 2014, 28, 121-148. [CrossRef]

78. Clemente, F.; Blair, H.; Trokel, N. Corporate Tax Chartbook: How Corporations Rig the Rules to Dodge the Taxes They Owe; Americans for TaxFairness: Washington, DC, USA, 2017.

79. Ahen, F.; Zettinig, P. What is the biggest question in CSR research? Foresight 2015, 17, 274-290. [CrossRef]

80. Egri, C.P.; Ralston, D.A. Corporate responsibility: A review of international management research from 1998 to 2007. J. Int. Manag. 2008, 14, 319-339. [CrossRef]

81. Frederick, W.C. Moving to CSR4: What to pack for the trip. Bus. Soc. 1998, 37, 40-59. [CrossRef]

82. Roberts, J.; Dörrenbächer, C. The futures of critical perspectives on international business. Crit. Perspect. Int. Bus. 2012, 8, 4-13. [CrossRef]

83. Jackson, T. Africa and international management: Why bother. AIB Insights 2004, 4, 6-8.

84. Faria, A. Border thinking in action: Should critical management studies get anything done? In Getting Things Done; Malin, V., Murphy, J., Siltaoja, M., Eds.; Emerald: Bingley, UK, 2014; pp. 277-300.

85. Banerjee, S.B. Whose land is it anyway? National interest, indigenous stakeholders, and colonial discourses: The case of the Jabiluka uranium mine. Org. Environ. 2000, 13, 3-38. [CrossRef]

86. Banerjee, S.B. Voices of the Governed: Towards a theory of the translocal. Organization 2011, 18, 323-344. [CrossRef]

87. Meriläinen, S.; Tienari, J.; Thomas, R.; Davies, A. Hegemonic academic practices: Experiences of publishing from the periphery. Organization 2008, 15, 584-597. [CrossRef]

88. Rivoli, P.; Waddock, S. "First they ignore you ... ": The time-context dynamic and corporate responsibility. Calif. Manag. Rev. 2011, 53, 87-104. [CrossRef]

89. Rotberg, R. Africa Emerges: Consummate Challenges, Abundant Opportunities; John Wiley \& Sons: New York, NY, USA, 2013.

90. Easterly, W. The White Man's Burden: Why the West's Efforts to Aid the Rest Have Done So Much Ill and So Little Good; The Penguin Press: New York, NY, USA, 2006.

91. Moyo, D. Dead Aid: Why Aid Is Not Working and How There Is A Better Way for Africa; Allen Lane: London, UK, 2009.

92. Moyo, J.; Gathigah, M. Africa's Billions that the Poor Won't Touch; Inter Press Service News Agency: Rome, Italy, 2014. 
93. Gates, B.; Gates, M. 3 myths that block progress for the poor. In Gates Annual Letter; Bill \& Melinda Gates Foundation: Seattle, WA, USA, 2014.

94. Wainaina, B. How to write about Africa. Granta, 19 January 2006.

95. Nwankwo, S. Renascent Africa: Rescoping the landscape of international business. Thunderbird Int. Bus. Rev. 2012, 54, 405-409. [CrossRef]

96. McNamee, T.; Pearson, M.; Boer, W. Africans Investing in Africa: Understanding Business and Trade, Sector by Sector; Palgrave Macmillan: Basingstoke, UK; New York, NY, USA, 2015.

97. Kruger, R.; Strauss, I. Africa Rising out of Itself: The Growth of Intra-African FDI; Columbia University Academic Commons: New York, NY, USA, 2015.

98. Adeleye, I.; Ibeh, K.; Kinoti, A.; White, L. (Eds.) The Changing Dynamics of International Business in Africa; Palgrave Macmillan: New York, NY, USA, 2015.

99. Klins, U.; Van Niekerk, J.H.; Smit, A. Africa. In The World Guide to CSR: A Country-by-Country Analysis of Corporate Sustainability and Responsibility; Visser, W., Tolhurst, N., Eds.; Greenleaf Publishing: Sheffield, UK, 2010; pp. 2-14.

100. Whitley, R. Divergent Capitalisms: The Social Structuring and Change of Business Systems; Oxford University Press: New York, NY, USA, 1999.

101. Curnow, R.; Kermeliotis, T. African consumers 'underestimated' by Western firms. CNN.com, 5 July 2012.

102. International Finance Corporation (IFC). The Business of Health in Africa: Partnering with the Private Sector to Improve People's Lives; International Finance Corporation: Washington, DC, USA, 2008.

103. Scherer, A.G.; Palazzo, G. The new political role of business in a globalized world: A review of a new perspective on CSR and its implications for the firm, governance, and democracy. J. Manag. Stud. 2011, 48, 899-931. [CrossRef]

104. Hajer, M. Policy without polity? Policy analysis and the institutional void. Policy Sci. 2003, 36, 175-195. [CrossRef]

105. Donaldson, T.; Preston, L.E. The stakeholder theory of the corporation: Concepts, evidence, and implications. Acad. Manag. Rev. 1995, 20, 65-91. [CrossRef]

106. Freeman, R.E.; Velamuri, S.R. A new approach to CSR: Company stakeholder responsibility. In Corporate Social Responsibility: Reconciling Aspiration with Application; Kakabadse, A., Morsing, M., Eds.; Palgrave MacMillan: New York, NY, USA, 2006; pp. 9-23.

107. Aguilera, R.V.; Jackson, G. The cross-national diversity of corporate governance: Dimensions and determinants. Acad. Manag. Rev. 2003, 28, 447-465. [CrossRef]

108. Hoskisson, R.E.; Eden, L.; Lau, C.M.; Wright, M. Strategy in Emerging Economies. Acad. Manag. J. 2000, 43, 249-267.

109. Husted, B.W.; Allen, D.B. Corporate social responsibility in the multinational enterprise: Strategic and institutional approaches. J. Int. Bus. Stud. 2006, 37, 838-849. [CrossRef]

110. Zhao, M.; Tan, J.; Park, S.H. From voids to sophistication: Institutional environment and MNC CSR crisis in emerging markets. J. Bus. Ethics 2014, 122, 655-674. [CrossRef]

111. Aguilera, R.V.; Jackson, G. Comparative and international corporate governance. Acad. Manag. Ann. 2010, 4, 485-556. [CrossRef]

112. Karam, C.M.; Jamali, D. Gendering CSR in the Arab Middle East. Bus. Ethics Q. 2012, 23, 31-68. [CrossRef]

113. Meyer, K.E. Perspectives on multinational enterprises in emerging economies. J. Int. Bus. Stud. 2004, 35, 259-276. [CrossRef]

114. Meyer, K.E.; Estrin, S.; Bhaumik, S.K.; Peng, M.W. Institutions, resources, and entry strategies in emerging economies. Strat. Manag. J. 2009, 30, 61-80. [CrossRef]

115. Alvesson, M. Do we have something to say? From re-search to roi-search and back again. Organization 2013, 20, 79-90. [CrossRef]

116. Scott, W.R. Institutions and Organizations: Ideas, Interests, and Identities, 4th ed.; SAGE Publications Inc.: Thousand Oaks, CA, USA, 2014.

117. Baum, J.A. Organizational ecology. In Studying Organization: Theory and Method; Clegg, S.R., Hardy, C., Eds.; SAGE Publications: Thousand Oaks, CA, USA, 1999; pp. 71-108.

118. North, D.C. Institutions, Institutional Change and Economic Performance; Cambridge University Press: New York, NY, USA, 1990. 
119. Bell, W. Choosing your future. In Viable Utopian Ideas: Shaping a Better World; Shostak, A.B., Ed.; ME Sharpe Inc.: Armonk, NY, USA, 2003; pp. 151-159.

120. Hofstede, G.; Van Deusen, C.A.; Mueller, C.B.; Charles, T.A.; The Business Goals Network. What goals do business leaders pursue? A study in fifteen countries. J. Int. Bus. Stud. 2002, 33, 785-803. [CrossRef]

121. Peng, M.W.; Pleggenkuhle-Miles, E.G. Current debates in global strategy. Int. J. Manag. Rev. 2009, 11, 51-68. [CrossRef]

122. Hamm, B. The study of futures, and the analysis of power. Futures 2010, 42, 1007-1018. [CrossRef]

123. Ietto-Gillies, G. Transnational Corporations: Fragmentation Amidst Integration; Routledge: London, UK, 2002.

124. Wherry, F.F. The varieties of value. Contemp. Sociol. J. Rev. 2013, 42, 183-189. [CrossRef]

125. Amaeshi, K.; Adi, A.; Ogbechie, C.; Amao, O. Corporate Social Responsibility in Nigeria: Western Mimicry or Indigenous Influences? SSRN: Rochester, NY, USA, 2006.

126. Dartey-Baah, K.; Amponsah-Tawiah, K. Exploring the limits of Western corporate social responsibility theories in Africa. Int. J. Bus. Soc. Sci. 2011, 2, 126-137.

127. World Business Council for Sustainable Development (WBCSD). Corporate Social Responsibility: Making Good Business Sense; World Business Council for Sustainable Development: Geneva, Switzerland, 2000.

128. Whelan, G.; Moon, J.; Grant, B. Corporations and citizenship arenas in the age of social media. J. Bus. Ethics 2013, 118, 777-790. [CrossRef]

129. Easterly, W. Trust the development experts—All 7bn. Financial Times, 28 May 2013.

130. Diamond, J. The World until Yesterday: What Can We Learn from Traditional Societies? Penguin: New York, NY, USA, 2012.

131. Coase, R.H. The nature of the firm. Economica 1937, 4, 386-405. [CrossRef]

132. Williamson, O.E. Markets and Hierarchies: Analysis and Antitrust Implications; Free Press: New York, NY, USA, 1975.

133. Rodrigues, S. Understanding the Environments of Emerging Markets: The Social Costs of Institutional Voids. Available online: http:/ / www.erim.eur.nl/news/detail/3160-farewell-address-understanding-theenvironments-of-emerging-markets/\#sthash.uDL2vctV.dpuf (accessed on 12 October 2013).

134. Dacin, M.T.; Dacin, P.A.; Tracey, P. Social entrepreneurship: A critique and future directions. Org. Sci. 2011, 22, 1203-1213. [CrossRef]

135. Zahra, S.A.; Gedajlovic, E.; Neubaum, D.O.; Shulman, J.M. A typology of social entrepreneurs: Motives, search processes and ethical challenges. J. Bus. Ventur. 2009, 24, 519-532. [CrossRef]

136. Kalvet, T.; Barnard, H.; Tiits, M. Institutional voids as a trigger for the emergence of born global production and innovation networks. In Proceedings of the 35th DRUID Celebration Conference, Barcelona, Spain, 17-19 June 2013.

137. Mair, J.; Marti, I. Entrepreneurship in and around institutional voids: A case study from Bangladesh. J. Bus. Ventur. 2009, 24, 419-435. [CrossRef]

138. Drucker, P.F. Management: Tasks, Practices, Responsibilities; Harper \& Row: New York, NY, USA, 1974.

139. Adams, K.; Nayak, B.S.; Koukpaki, S. Critical perspectives on "manufactured" risks arising from Eurocentric business practices in Africa. Crit. Perspect. Int. Bus. 2017, 14, 210-229. [CrossRef]

140. Harris, M.; Weisberger, E.; Silver, D.; Macinko, J. 'They hear "Africa" and they think that there can't be any good services'-perceived context in cross-national learning: A qualitative study of the barriers to Reverse Innovation. Glob. Health 2015, 11, 1. [CrossRef] [PubMed]

141. Doyle, M. Africans' remittances outweigh Western aid. BBC News, 17 April 2013.

142. WorldVision. Coca-Cola Partners with World Vision to Bring Clean Water and Sanitation. Available online: https: / www.worldvision.org/corporate/2017/07/21/coca-cola-world-vision/ (accessed on 22 June 2018).

143. BASF Group. BASF Report 2017: Economic, Environmental and Social Performance; BASF SE: Ludwigshafen, Germany, 2018.

144. Aletter, F.; von den Burg, K.; Zanella, I. (Eds.) Corporate Social Responsibility in South Africa-As Practiced by South African and German Companies; Southern African-German Chamber of Commerce and Industry: Johannesburg, South Africa, 2010.

145. Jerven, M. Poor Numbers: How We Are Misled by African Development Statistics and What To Do about It; Cornell University Press: Ithaca, NY, USA, 2013.

146. Kenyatta, U. Kenya's Uhuru Kenyatta urges Africa to give up aid. BBC News, 12 June 2015. 
147. Karnani, A. Corporate social responsibility does not avert the tragedy of the commons. Case study: Coca-Cola India. Econ. Manag. Financ. Mark. 2014, 9, 11-23.

148. Ahen, F. 'Second best' institutions and global sustainability. In International Business: New Challenges, New forms, New Perspectives; Harris, S., Kuivalainen, O., Stoyanova, V., Eds.; Palgrave Macmillan: Basingstoke, UK, 2012; pp. 41-58. [CrossRef]

149. Vogel, D.J. The Market for Virtue: The Potential and Limits of Corporate Social Responsibility; Brookings Institution Press: Washington, DC, USA, 2005.

150. Forstater, M.; Zadek, S.; Guang, Y.; Yu, K.; Xiao Hong, C.; George, M. Corporate Social Responsibility in African Development; Working Paper; The Institute of West-Asian and African Studies of the Chinese Academy of Social Sciences: Beijing, China, 2010.

151. Harvey, D. The "new imperialism": Accumulation by dispossession. Actuel Marx 2004, 1, 71-90. [CrossRef]

152. Vogel, D.J. Is there a market for virtue? The business case for corporate social responsibility. Calif. Manag. Rev. 2005, 47, 19-45.

153. Stout, L.A. The Shareholder Value Myth: How Putting Shareholders First Harms Investors, Corporations, and the Public; Berrett-Koehler Publishers: San Francisco, CA, USA, 2012.

154. Shirley, A. Which Are the World's Most Environmentally Friendly Countries? World Economic Forum: Cologny, Switzerland, 2016.

155. Ahen, F.; Zettinig, P. Institutional and market forces: The dominant logic of strategic corporate responsibility and innovative value co-creation. In International Business, Sustainability and Corporate Social Responsibility (Advances in Sustainability and Environmental Justice); Gonzalez-Perez, M.A., Leonard, L., Eds.; Emerald Group Publishing Ltd.: Bingley, UK, 2013; Volume 11, pp. 97-131.

156. Mwakideu, C. Northern Ghana 'poor' despite NGOs presence. DW.com, 13 November 2016.

157. Shamir, R. The age of responsibilization: On market-embedded morality. Econ. Soc. 2008, 37, 1-19. [CrossRef]

158. Moseley, W.G. Graduation advice for aspiring humanitarians. AlJazeera.com, 28 May 2014.

159. Chiminazzo, T. Etica ed Economia: Il Mercato e L'economia Nell'era della Globalizzazione; FrancoAngeli s.r.l.: Milano, Italy, 2007.

160. Bilkey, W.J.; Nes, E. Country-of-origin effects on product evaluations. J. Int. Bus. Stud. 1982, 13, 89-100. [CrossRef]

161. Harris, M.; Macinko, J.; Jimenez, G.; Mahfoud, M.; Anderson, C. Does the origin of research affect perception of research quality and relevance? A national trial of US public health academics. BMJ Open 2015, 5, e008993. [CrossRef] [PubMed]

162. Oxfam. Rigged Rules and Double Standards: Trade, Globalisation, and the Fight against Poverty; Oxfam International: Oxford, UK, 2002.

163. Standing, G. The Corruption of Capitalism: Why Rentiers Thrive and Work Does Not Pay; Biteback Publishing: London, UK, 2016.

164. Ostrom, E. Governing the Commons: The Evolution of Institutions for Collective Action; Cambridge University Press: Cambridge, UK, 1990.

165. Stiglitz, J.E. The Price of inequality: How Today's Divided Society Endangers Our Future; W. W. Norton \& Company: New York, NY, USA, 2012.

166. Suchman, M.C. Managing legitimacy: Strategic and institutional approaches. Acad. Manag. Rev. 1995, 20, 571-610. [CrossRef]

167. Crane, A. Modern slavery as a management practice: Exploring the conditions and capabilities for human exploitation. Acad. Manag. Rev. 2013, 38, 49-69. [CrossRef]

168. Mantere, S.; Pajunen, K.; Lamberg, J.-A. Vices and virtues of corporate political activity: The challenge of international business. Bus. Soc. 2009, 48, 105-132. [CrossRef]

169. Geppert, M.; Dörrenbächer, C. Politics and power within multinational corporations: Mainstream studies, emerging critical approaches and suggestions for future research. Int. J. Manag. Rev. 2014, 16, 226-244. [CrossRef]

170. Clegg, S.R. Why is organization theory so ignorant? The neglect of total institutions. J. Manag. Inq. 2006, 15, 426-430. [CrossRef]

171. Goffman, E. On the characteristics of total institutions. In Proceedings of the Symposium on Preventive and Social Psychiatry, Washington, DC, USA, 15-17 April 1957; pp. 43-84. 
172. Amankwah-Amoah, J. Global business and emerging economies: Towards a new perspective on the effects of e-waste. Technol. Forecast. Soc. Chang. 2016, 105, 20-26. [CrossRef]

173. Arts, B. Non-state actors in global governance: Three faces of power. In Preprints (2003/04); Max Planck Institute for Research on Collective Goods: Bonn, Germany, 2003.

174. Basso, F. Il protezionismo? Un errore Non è il commercio mondiale che ha tagliato postidilavoro. Corriere della Sera, 17 November 2016.

175. Lynn, R.; Vanhanen, T. IQ and the Wealth of Nations; Praeger Publishers: Westport, CT, USA, 2002.

176. Weisbord, R.G. The King, the Cardinal and the Pope: Leopold II's genocide in the Congo and the Vatican. J. Genocide Res. 2003, 5, 35-45. [CrossRef]

177. Christensen, J. The looting continues: Tax havens and corruption. Crit. Perspect. Int. Bus. 2011, 7, 177-196. [CrossRef]

178. Branson, F. Why the poor don't deserve your pity. TEDxOxford, 4 August 2015.

179. Rashid, S. Watchman, who watches thee? Donors and corruption in less-developed countries. Indep. Rev. 2006, 10, 411-418.

180. Contractor, F.J. Tax avoidance by multinational companies: Methods, policies, and ethics. AIB Insights 2016, $16,10-13$.

181. Schock, S. Corporate tax avoidance costs Africa dearly. DW, 6 July 2015.

182. Madeley, J. Big Business, Poor Peoples: How transnational Corporations Damage the World's Poor; Zed Books Ltd.: London, UK, 2009.

183. Rodrik, D. Second-best institutions. Am. Econ. Rev. 2008, 98, 100-104. [CrossRef]

184. Woodson, C.G. The Mis-Education of the Negro; The Associated Publishers, Inc.: Washington, DC, USA, 1933.

185. EUCOM. Countries and Regions: West Africa. Available online: http://ec.europa.eu/trade/policy/ countries-and-regions/regions/west-africa/ (accessed on 24 June 2018).

186. The Wall Street Journal. Africa's Historic Shift from Aid to Trade (video; 30 March 2015). Available online: http:/ / www.wsj.com/video/africas-historic-shift-from-aid-to-trade/078C8CAE-6035-4FBD-9777EE549D8153DB.html (accessed on 6 July 2018).

(C) 2018 by the authors. Licensee MDPI, Basel, Switzerland. This article is an open access article distributed under the terms and conditions of the Creative Commons Attribution (CC BY) license (http:/ / creativecommons.org/licenses/by/4.0/). 